New Zealand Journal of Forestry Science

\title{
Potential effectiveness of low-density plantings of mānuka (Leptospermum scoparium) as an erosion mitigation strategy in steeplands, northern Hawke's Bay, New Zealand
}

\author{
Michael Marden ${ }^{1, *}$, Suzanne Lambie ${ }^{2}$ and Chris Phillips ${ }^{3}$ \\ ${ }^{1} 31$ Haronga Road, Gisborne 4010, New Zealand \\ ${ }^{2}$ Manaaki Whenua - Landcare Research, Private Bag 3127, Hamilton 3240, New Zealand \\ ${ }^{3}$ Manaaki Whenua - Landcare Research, PO Box 69041, Lincoln 7640, New Zealand \\ *Corresponding author: mardemm@landcareresearch.co.nz \\ (Received for publication 11 November 2019; accepted in revised form 12 October 2020)
}

\begin{abstract}
Background: Government-funded schemes introduced to encourage new afforestation (exotic and indigenous) include the establishment of low-density plantings ( $\leq 1100$ stems ha $^{-1}$ ) of mānuka (Leptospermum scoparium Forster et Forster f.) on steeplands with severe erosion susceptibility and considered marginal for pastoral production. There is, however, little quantitative data to establish when (i.e., how many years after planting) these plantings likely afford effective mitigation against the initiation of shallow landslides.
\end{abstract}

Methods: Permanent sample plots [PSPs] were established within mānuka plantings established in northern Hawke's Bay, New Zealand, where above-ground growth metrics were recorded for plantings on three landform units including interfluve ridges, colluvial slopes, and slopes affected by landslides. The root systems of a small sub-set of mānuka were hand-excavated and whole plants destructively sampled for analysis of differences in allometric relationships by year, between landforms, and for comparison of the above-ground components of trees within PSPs.

Results: Six years after planting, interfluves and colluvial slopes were understocked by between 10 and $25 \%$, and by up to $45 \%$ on sites previously affected by landslides. Root collar diameter (RCD) explained between 92 and $99 \%$ of the variation in mānuka biomass. The overall above- and below-ground metrics for mānuka excavated from interfluves were significantly greater $(P<0.05)$ than those excavated from landslides. Irrespective of landform type, the greatest proportion of the mean total root length and biomass was found in the top $0-0.5 \mathrm{~m}$ of the soil profile, within a $0.5-\mathrm{m}$ radius of the stump, and importantly, no roots were found below $1 \mathrm{~m}$ depth. The timing (years after planting) to attain canopy closure and root occupancy, if stands of mānuka were to remain fully stocked, varies between landforms and would likely occur between 6.5 and 9 years after planting. However, variable rates in planting density, and of plant mortality, resulting in under-stocking would significantly delay this timing, particularly on landslide-affected slopes.

Conclusions: Mānuka planted at densities $\leq 1100$ stems ha $^{-1}$ are unlikely to provide effective erosion mitigation on steep land until significant root mass develops below the depth of the shear plane at which most landslides occur. Increasing the planting density, reducing early seedling mortality by better management of weed competition, and/or their replacement (blanking) would probably improve the erosion mitigation effectiveness of future low-density mānuka plantings.

Keywords: canopy growth; erosion mitigation; landforms; Leptospermum scoparium Forster et Forster f.; mānuka; plantings; root growth 


\section{Introduction}

Significant areas of New Zealand's steep hill country are now considered to be marginal for pastoral production due to high current erosion rates generated by shallow landslides. In such high-risk areas, woody indigenous shrublands formerly considered a hindrance to pastoral farming can play an important role in mitigating erosion (Marden \& Rowan 1993; Bergin et al. 1995; Ministry for Primary Industries 2015a, 2015b, 2016). There is consensus that within a 10 -year period, natural stands of early colonising indigenous shrubland and forest species mānuka (Leptospermum scoparium) (Forster et Forster f.)) and kānuka (Kunzea species (A. Rich) J. Thompson) attain canopy closure. In the event of a major storm, the incidence of landsliding in these closed canopied stands is reduced by $\sim 65 \%$ relative to adjacent pasture, increasing to $\sim 90 \%$ at 20 years (Bergin et al. 1995), comparable with that for areas of mature indigenous forest (Marden \& Rowan 1993). Shrublands also provide additional environmental benefits and services including increasing woody biomass and carbon stocks, and improvements in stream health and water quality.

Since Cyclone Bola in 1988, government-funded schemes, including the Afforestation Grant Scheme (Ministry for Primary Industries 2015a) and the Permanent Forest Sink Initiative (Ministry for Primary Industries 2015b), have encouraged establishment of new areas of forest (exotic and indigenous) and natural reversion of shrubland areas on grasslands with severe erosion risk. Together with the more recently announced One Billion Trees Fund (Ministry for Primary Industries 2018), these schemes are likely to target $\sim 1.45$ million ha of steep, erosion-prone pastoral hill country considered marginal for long-term agriculture, and areas of short-rotation exotic forest identified in the National Environmental Standards for Plantation Forestry (Ministry for the Environment 2018) as being at high erosion risk and better suited to transitioning to permanent indigenous shrubland or forest (Trotter et al. 2005).

In recent years mānuka has been increasingly valued for its high-value honey and oil with unique anti-bacterial properties. This has led to manuka, produced as nurseryraised, container-grown seedlings, being planted at fixed spacings across extensive areas of marginal pastoral hill country. Planting densities at establishment are typically $\leq 1111$ stems ha $^{-1}$ because at higher planting densities canopy closure occurs earlier, thereby supressing flowering development and ultimately affecting the economics of honey production. There is an often-stated expectation that these low-density plantings of mānuka will in time provide effective long-term erosion control. However, there is little quantitative evidence to support this. Sites planted at densities that enable canopy closure and root occupancy in the shortest time are intuitively likely to provide protection earliest. Conversely, planting densities at several orders of magnitude less than is found within stands of naturally reverting shrubland are likely to prolong the 'risk' to storm-initiated landsliding. Thus, in areas of marginal land where erosion susceptibility is high, a tension exists between deriving economic gains from honey and reducing the period of risk until effective erosion control is afforded by these plantings.

Much of the research relevant to understanding the role of hydrological and mechanical influences in the mitigation of erosion by mānuka and kānuka shrubland has largely been derived from investigations undertaken within areas of natural reversion. At the stand level, previous studies have included investigations of water balance components (e.g. interception of rainfall) (Aldridge \& Jackson 1968; Rowe et al. 1999), mitigation of storm effects (e.g., landslide prevention) by closedcanopy stands of shrubland species (Marden \& Rowan 1993; Hicks 1991; Bergin et al. 1995), and their use as a bio-engineering agent on roadsides and in mining rehabilitation (Watson et al. 1998). Studies of individual plants have involved the measurement of root growth (spread, depth and biomass) (Watson \& O'Loughlin 1985; Watson et al. 1995; Marden et al. 2018a; b), rates of root decay (Watson et al. 1997,1999) and of root tensile strength (Watson \& Marden 2004). While previous attempts to specifically model soil-root reinforcement and slope safety factors for these shrubland species have largely been based on data collected from naturally reverting stands (Watson \& O'Loughlin 1985; Ekanayake et al. 1997, 2004; Watson et al. 1999), there have been no similar studies for either species established at lowdensities. Thus, to better understand the effectiveness of low-density plantings in mitigating the occurrence of storm-initiated landsliding on steep hill country, a 41.5ha plantation of mānuka was established in 2012 on pastoral farmland near Lake Tutira in northern Hawke's Bay, and with a history of severe to very severe shallow landsliding, was selected for further studies.

Typically, such terrain comprises several different landform units, including landslide-scarred hillslope basins separated by broad interfluve ridges and spurs, and localised depositional units in the form of colluvial slopes (Carson \& Kirby 1972).

Most incidences of shallow landsliding in the North Island's East Coast region are initiated by infrequent heavy rainfall events with a ca 10 -year return interval (Marden \& Phillips 2015). Thus the key to establishing the time (years after establishment) required for low density plantings to effectively mitigate the occurrence of shallow landsliding is to determine the effect of site conditions on mānuka growth through the acquisition of time-series data for the period when juvenile plantings are at their most vulnerable to hillslope failure.

\section{Methods \\ Site and trial design}

The study site (Fig. 1) is located at Lake Tutira $\left(176^{\circ}\right.$ 54' $1044 \mathrm{E}, 39^{\circ}$ 14' $0044 \mathrm{~S}$ ), northern Hawke's Bay, New Zealand, where plantings were established at the southern end of a northwest-facing scarp comprising Tertiary-aged sandstones and silty mudstones interbedded with limestone and conglomerates (Mazengarb \& Speden 2000). The moderately steep to steep slopes $\left(10-55^{\circ}\right)$ are classified as Land Use Capability Class 7 (National Water and Soil Conservation Organisation 1976) representative of erosion-prone, 


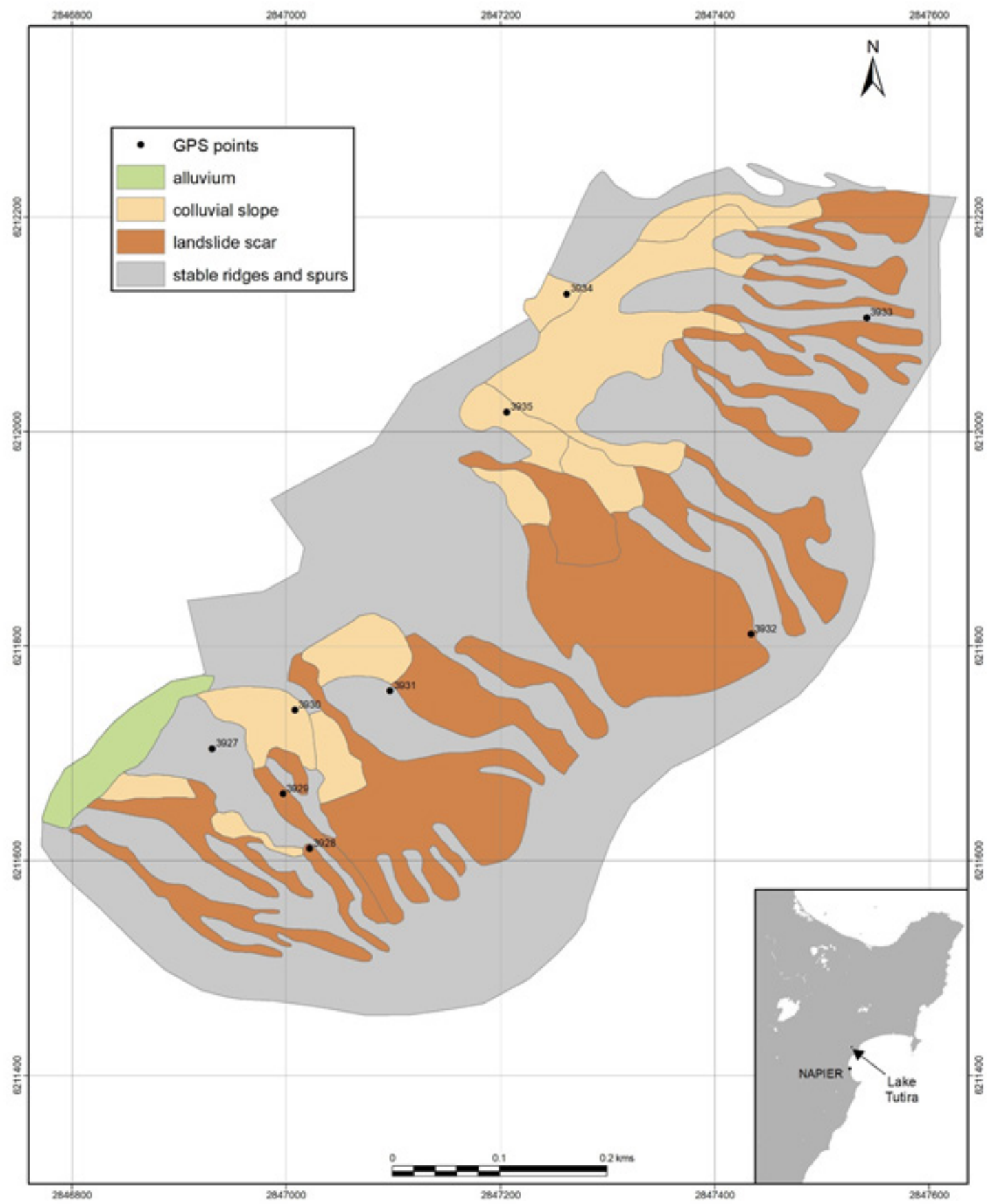

FIGURE 1: Map showing the location of PSPs established within space-planted mānuka plantings established in 2012 , relative to the different landform units at Lake Tütira (bottom inset shows location), northern Hawke's Bay, New Zealand.

soft-rock hill country throughout the North Island, much of which is considered marginal for long-term pastoral use.

Three broad-scale landforms were identified and mapped into four units: (i) former landslide scars (hereafter referred to as landslides) predominantly located on mid-slopes (11.5 ha, $27.4 \%$ of study area); (ii) colluvial slopes where landslide debris comprising thick deposits of mixed soil and tephra has accumulated as colluvium (4.9 ha, $11.5 \%$ of study area); and (iii) stable interfluve ridges and spurs (hereafter referred to as interfluves) with little sign of slope instability (Fig. 2), and where relict forest soil and tephric deposits have remained intact ( $22.3 \mathrm{ha}, 53 \%$ of study area). Plots were not established on areas of alluvial valley floor $(0.65 \mathrm{ha}$, $1.5 \%$ of study area) or on slopes so 'disturbed' it was difficult to identify a specific landform unit on which to locate a permanent sample plot $(2.78$ ha, $6.6 \%$ of study area). The physical site characteristics for each landform are listed in Table 1.

Across the study area, the overlying regolith is largely reworked colluvium and airfall tephra that is susceptible 


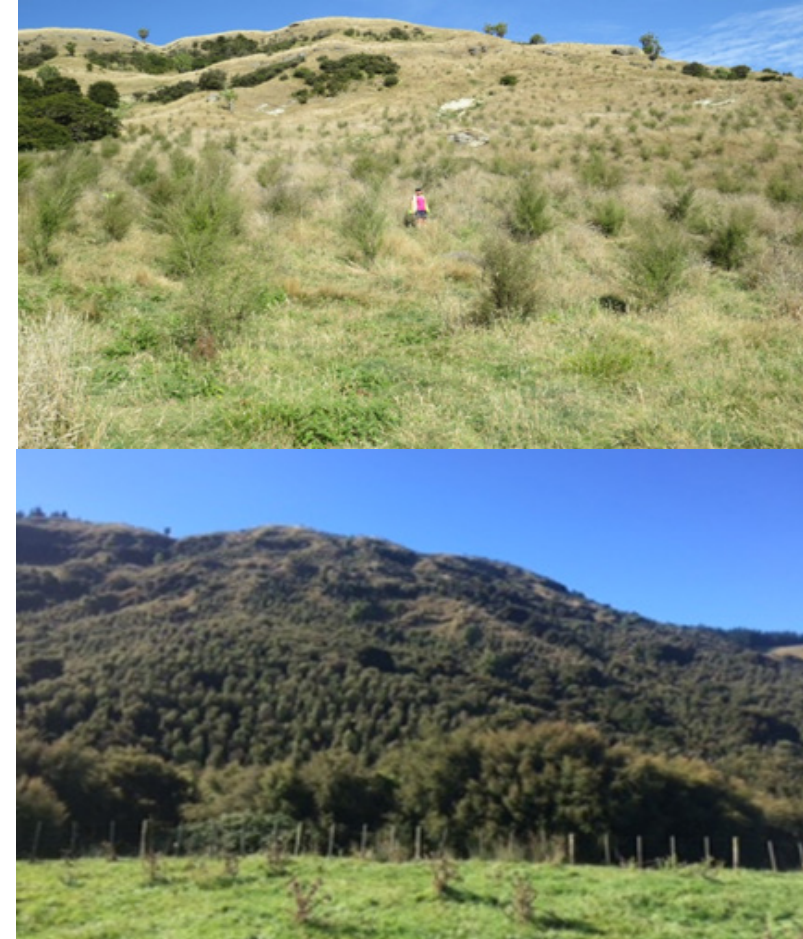

FIGURE 2: Mānuka planted in 2012 on interfluves (lower slopes), and landslide-scarred upper slopes with patches of remnant kanuka at Lake Tūtira, northern Hawke's Bay, New Zealand. Photographs were taken in 2015 (top) 3 years after planting, and in 2018 (bottom) 6 years after planting. Lower photo courtesy of Blue McMillan.

to a range of different erosion processes, particularly shallow landslides. Soils on interfluve ridges and spurs are largely undisturbed Typic Orthic Allophanic (Hewitt 2010) silt loams comprising a $0.2 \mathrm{~m}$ thick A-horizon containing Taupo Tephra (erupted $\sim 1720$ years BP) underlain by a $0.15 \mathrm{~m}$ thick B-horizon of Waimihia Lapilli (erupted $\sim 3280$ years BP), and $0.4 \mathrm{~m}$ of older

TABLE 1: Physical characteristics of study site at Lake Tutira, northern Hawke's Bay, New Zealand.

\begin{tabular}{|c|c|}
\hline Parameter & Details \\
\hline LUC Class & $7 e 3^{1}$ \\
\hline Slope group & $\mathrm{E}\left(21-25^{\circ}\right)$ and $\mathrm{F}\left(26-35^{\circ}\right)$ \\
\hline NZ Soil Classification ${ }^{2}$ & $\begin{array}{l}\text { Typic Immature Pallic, } \\
\text { Typic Orthic Allophanic }\end{array}$ \\
\hline Geology ${ }^{3}$ & $\begin{array}{l}\text { Pliocene-age mudstone, } \\
\text { sandstone, limestone }\end{array}$ \\
\hline $\begin{array}{l}\text { Erosion severity and } \\
\text { type }\end{array}$ & $\begin{array}{l}\text { Extreme shallow landsliding, } \\
\text { slight tunnel gullying }\end{array}$ \\
\hline Vegetation type & Low producing pasture \\
\hline Elevation (asl) & $200-375 \mathrm{~m}$ \\
\hline Aspect & Northwest facing \\
\hline
\end{tabular}

${ }^{1}$ Page (1976)

${ }^{2}$ Hewitt (2010)

${ }^{3}$ Mazengarb \& Speden (2000) finer-grained tephra of mid-Holocene age (Eden et al. 1993) giving a mean depth of $\sim 0.75 \mathrm{~m}$. They are free draining with tunnel gullies forming within the Waimihia Lapilli. Soils overlie a highly weathered C-horizon of mudstone and/or sandstone and limestone. In contrast, where slopes are steepest, storm events have previously resulted in extensive landsliding (Glade 1996) with most failures coinciding with the colluvium-bedrock interface, thereby stripping much of the original coverbed materials. Subsequent soil deposition onto exposed bedrock is largely by slope wash processes resulting in soil depths that are rarely $>\sim 0.3 \mathrm{~m}$ deep. These soils are described as skeletal and infertile, and classified as Typic Immature Pallics (Hewitt 2010). The deepest soils ( 1.0 $\mathrm{m}$ ) are found on colluvial slopes where storm-initiated landslide debris intermixed with tephra and relict forest soils have accumulated over many years (Preston 1999).

The study site experiences lengthy dry periods, a mean annual temperature above 15 degrees, and $~ 1300$ $\mathrm{mm} \mathrm{yr}^{-1}$ of annual rainfall. The region is regularly subjected to heavy rainfall events. The most recent event was in 1988 (Cyclone Bola), producing $753 \mathrm{~mm}$ in 4 days and together with previous storm events, accounting for the loss of soil from $>25 \%$ of the study area.

In 2012, an area of 41.5 ha (Fig. 1) was planted with 1-year-old seedlings raised in Lannen 64FD container trays. Plant specifications required seedlings to be between 0.2 and $0.3 \mathrm{~m}$ tall and to have a stem diameter measured at the root collar of $2.0-3.0 \mathrm{~mm}$.

Seedings were planted in parallel lines along slope contours at a spacing of $3 \times 3 \mathrm{~m}$ (i.e. 1111 stems ha-1). An independent audit carried out a year after planting confirmed that the planting density requirement (stocking rate) of 1111 stems ha ${ }^{-1}$ had been met but varied between 900 and 1300 stems ha $^{-1}$ across different parts of the landscape (James Powrie pers. comm.).

In 2015, three PSPs (each $20 \times 20 \mathrm{~m}$ ) (Hurst \& Allen 2007) were established on each landform. The centre point of each plot was marked with a wooden post to which was nailed an aluminium tag with an identification number. To assist with relocating each plot a tall, white fibreglass rod was placed next to the post and the position was fixed using Global Positioning System technology (GPS). GPS coordinates for the PSPs are listed in Appendix Table A1.

\section{Data collection \\ Plot-based measurements}

In 2015 (3 years after planting on-site), and again in 2016 (4 years after planting), for all live single-stemmed mānuka (Fig. 3) present within each of the 9 PSPs, diameter at breast height (DBH at $1.4 \mathrm{~m}$ above-ground level on the upslope side of each plant), root-collar diameter (RCD, measured over bark at ground level), plant height, and maximum canopy spread (measured in two directions at right angles and averaged) were measured.

On occasion, multiple mānuka seedlings (Fig. 3) were present within a single container supplied by the nursery. When established in the field, they grew as a cluster comprising numerous individual plants, each 


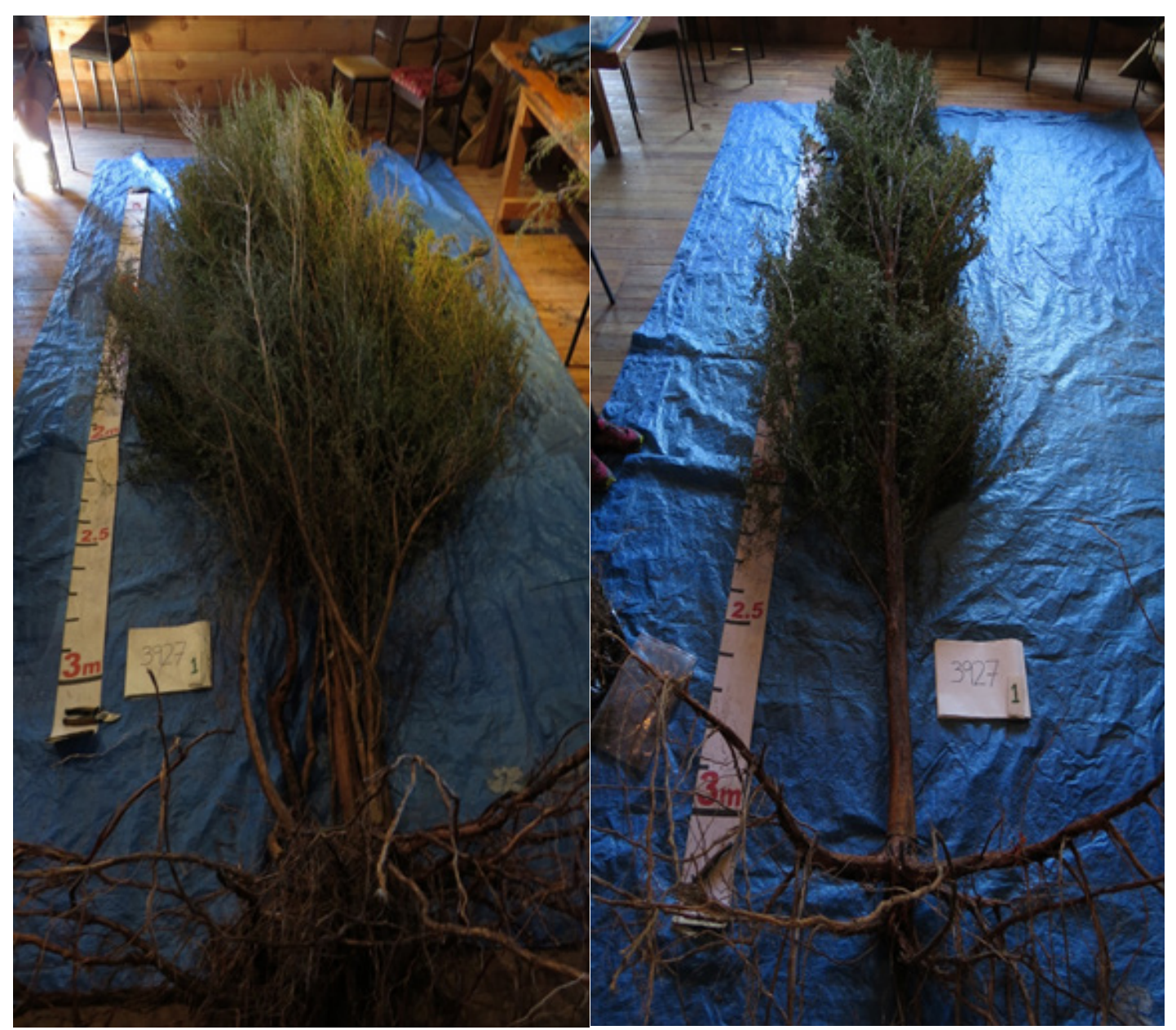

FIGURE 3: Contrasting canopy dimensions and root configuration between multi-stemmed (left) and single-stemmed (right) mānuka excavated 6 years after planting, Lake Tutira, northern Hawke's Bay, New Zealand.

with its own root system. For clusters of plants, stem height, RCD, and DBH were measured for each stem but canopy diameter (as measured for single-stemmed mānuka) was measured for the cluster as-a-whole.

The initial stocking rate within PSPs at the time of the first measurement period (2015) was based on the number of live trees present and any gaps in the regularly spaced rows that we assumed would have been planted. The 2015 data were used to establish the proportion (\%) of mānuka presumed to have died during the 3-year period since planting in 2012, and as a measure of further plant losses during the remainder of the trial period (2015-2018) for which there was a clear explanation.
No plot-based data were collected in 2017, and when measurements resumed in 2018 data were collected from only 2 of the 3 PSPs initially installed on each of the 3 landforms (i.e. from 6 of the original 9 PSPs) (Table 2). Height, DBH, RCD, canopy, and AGB, though not measured annually, demonstrate incremental changes in these parameters during the term of the measurement period.

\section{Root system excavation and measurements}

In 2015, the root systems of nine mānuka were handexcavated, and in 2016 a further nine mānuka were excavated. Trees selected for extraction were identified in the field at the time of measuring trees within PSPs

TABLE 2: Characteristics of major landforms at Lake Tūtira, northern Hawke's Bay, New Zealand.

\begin{tabular}{llllll}
\hline Landform & $\begin{array}{l}\text { Area (\% of } \\
\text { study area) }\end{array}$ & $\begin{array}{l}\text { Slope } \\
\text { (degrees) }\end{array}$ & $\begin{array}{l}\text { Regolith } \\
\text { depth (m) }\end{array}$ & $\begin{array}{l}\text { Erosion } \\
\text { risk }\end{array}$ & Erosion type \\
\hline Former landslide scars & 27.4 & $20-35$ & $0.3-0.5$ & High & Shallow landslide \\
Colluvial slopes & 11.5 & $<20$ & $>1$ & Very low & Tunnel gully \\
Interfluves & 53 & $<20$ & 0.75 & Low & Channel widening \\
Alluvial valley infill & 1.5 & Flat & Unknown & High & Channel widening \\
Undefined landforms & 6.6 & $15-35$ & $0.3-0.75$ & High & Shallow landslide \\
\hline
\end{tabular}


and based on estimated heights and general stature representative of the smallest, medium and largest trees present within PSPs on each of the landform types. All excavations were located beyond the bounds of the PSPs installed on each of the 3 mapped landforms. No mānuka root systems were excavated in 2017. As the data from the 2015 and 2016 measurement periods indicated that there were no significant differences in the root metrics measured between mānuka plantings on stable interfluves and colluvial slopes, but that their metrics were significantly greater than for mānuka plantings on landslide sites, the sampling strategy was changed. In 2018, to better exhibit the influence of contrasting physical site factors between interfluve and landslide sites on the development of mānuka root systems and therefore the time (years after planting) it takes for root systems to attain full root-occupancy, and since future plantings are likely to target areas previously subjected to shallow landsliding, mānuka were excavated from these two landforms only. Furthermore, on account of the increased workload and costs associated with the excavation and processing of larger trees, the number of mānuka plants excavated from interfluve and landslide sites was reduced to two per landform (i.e. a total of four sample plants). No mānuka root systems were excavated from colluvial slopes in 2018. (Table 3).

Sample trees were cut at ground level and their height, canopy spread, RCD and DBH (where applicable) were measured. The above-ground components were then separated into branches, foliage, and stem. The separation between stems and branches for single and double leader shrubs was obvious as each stem originated at the root collar. For multi-stemmed clusters the individual plants were disentangled, making the separation between stems and branches easier. Where forking of the stem occurred, each fork was of a similar diameter, more upright, and of larger diameter than the foliage-bearing branches. Foliage and seed pods were hand-stripped from the branches and stem.

Root systems were hand excavated. Measurement methods followed well-established procedures (e.g. Watson et al. 1999; Marden et al. 2005, 2018a, b; Phillips et al. 2014, 2015; Giadrossich et al. 2017). Once removed from the ground, the root system of each plant was washed to remove adhering soil matter, photographed (Fig. 3) then partitioned into root bole (stump) and roots. Below-ground growth parameters included mean root depth and mean root spread of the lateral roots,

TABLE 3: Number of mānuka measured within PSPs and sample plants excavated in 2015, 2016 and 2018, 3, 4, and 6 years respectively, after planting at Lake Tutira, northern Hawke's Bay, New Zealand.

\begin{tabular}{lrrr}
\hline Measurement taken & \multicolumn{3}{c}{ Measurement Year } \\
& $\mathbf{2 0 1 5}$ & $\mathbf{2 0 1 6}$ & $\mathbf{2 0 1 8}$ \\
\hline PSPs & 9 & 9 & 6 \\
Total PSP plants & 346 & 391 & 307 \\
Excavated sample plants & 9 & 9 & 4 \\
\hline
\end{tabular}

hereafter referred to as root depth and root spread. The latter was taken as the mean of the maximum root length measured from root tip to root tip in two directions at right angles to each other. Root distribution by biomass and length relative to the root bole, was obtained by systematically dissecting the root systems into $0.5-\mathrm{m}$ radial and depth segments then sorted by diameter size classes, ( $<1 \mathrm{~mm}$ fibrous, $>1<2,2.1-5.0,5.1-10.0,10.1-$ $20.0 \mathrm{~mm}$ over bark) (Watson \& O'Loughlin 1990). Root length (excluding fibrous roots) within each of the root diameter size classes was measured by laying pieces of root end for end alongside a tape measure (Watson et al. 1999). The weight of the roots and root bole were calculated separately.

All plant components, both above- and below-ground, were oven-dried at $80{ }^{\circ} \mathrm{C}$ for $24 \mathrm{~h}$ or until no further weight loss was detectable then weighed to the nearest 0.1 g. Above-ground biomass (AGB), below-ground biomass (BGB) and root:shoot ratio were calculated using dry weight $(\mathrm{g})$.

\section{Data analysis}

Statistical differences in incremental change in tree height, DBH, RCD and canopy diameter of trees within PSPs were assessed using unbalanced ANOVA with least significant difference $(P<0.05)$ determining differences between years and/or landforms. This was also undertaken for excavated trees. Root spread, root depth, total AGB, total BGB, and total tree biomass of excavated plants were also assessed for differences between landforms and years using unbalanced ANOVA. All ANOVA analyses were undertaken using Genstat 18 (VSN International, UK). Data are presented as a mean with standard errors unless otherwise stated. Paired T-tests for RCD, DBH, height and canopy diameter were used to assess differences between mānuka within PSPs and excavated trees. All statistical analyses were considered significant if $P<0.05$ (Table 4).

\section{Allometry}

From PSP measurements, power regression using the equation $\left(y=a x^{b}\right)$ was used to fit mānuka RCD (over bark) and tree height data $(n=1044)$ for each of the study site landforms, and for mānuka excavated from across all landforms combined $(n=22)$ (Table 5). As RCD is measured at the intersection between the above and below-ground components of plants, and in seedlings stem taper is minimal, we used RCD in the analysis of tree allometry because it may serve as a better predictor of both above- and below-ground biomass (Wagner \& Ter-Mikaelian 1999). Using two-parameter exponential growth analysis $\left(y=a^{(b x)}\right)$, measurements of excavated trees were used to derive relationships between RCD and foliage, branches and stem biomass, total above-ground biomass (AGB), total below-ground biomass (BGB), total root biomass ( $>1 \mathrm{~mm}$ diameter), and total root length $(>1$ mm diameter). For multi-stemmed mānuka, regressions were applied to each stem for RCD, DBH, and height then summed to determine total tree biomass. All regression analyses were undertaken using Sigma Plot 13.0 (Systat Software, San Jose, CA). 


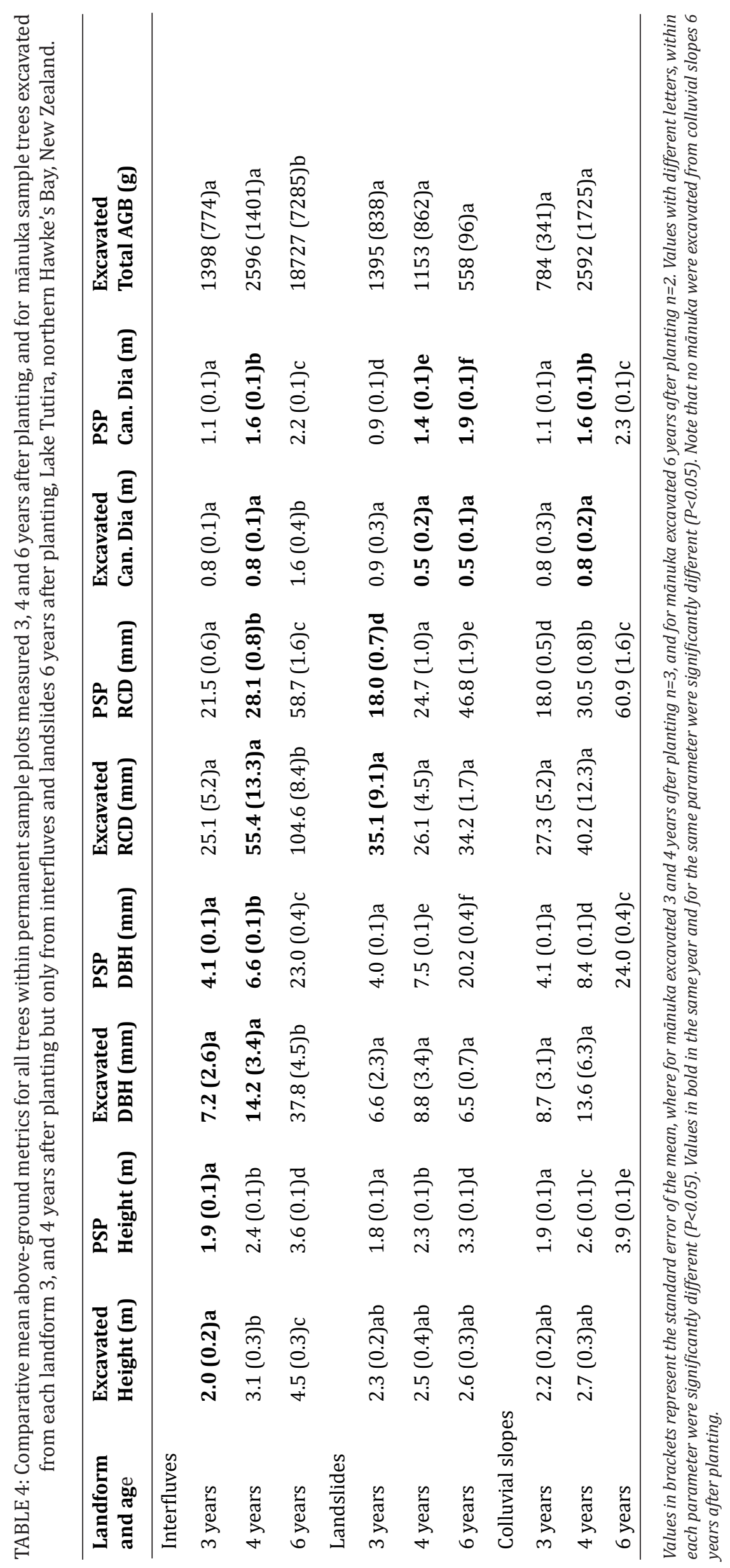


TABLE 5: Power analysis $\left(y=a x^{b}\right)$ of RCD against tree height for mānuka excavated 3, 4, and 6 years after planting across all landforms, and for PSP-based measurements, by landform type, Lake Tutira, northern Hawke's Bay, New Zealand.

\begin{tabular}{llllll}
\hline & $\mathbf{r}^{2}$ & $\boldsymbol{P}$ & $\mathbf{a}$ & $\mathbf{b}$ & SEE* $^{*}$ \\
\hline Excavated trees & 0.82 & $<0.001$ & 0.553 & 0.438 & 0.327 \\
PSP-based measurements & & & \\
Interfluve & 0.66 & $<0.001$ & 0.609 & 0.423 & 0.550 \\
Landslide & 0.64 & $<0.001$ & 0.587 & 0.695 & 0.395 \\
Colluvial slopes & 0.78 & $<0.001$ & 1.307 & 0.342 & 0.474 \\
\hline
\end{tabular}

*Standard error of the estimate

\section{Canopy closure and root occupancy prediction}

Extrapolation of measurements of incremental change in canopy diameter of mānuka within PSPs on each landform 3-, 4- and 6-years after planting were used to estimate when the crowns of individual trees in adjacent rows would likely form a closed canopy. Similarly, measurements of the mean root spread of excavated trees of equivalent age were used to assess the rate of lateral root extension across the gaps between planted rows. To estimate the influence of different planting density regimes on the time (years after planting) at which canopy closure and full soil-root occupancy would likely occur when plants were established at 1111 stems $\mathrm{ha}^{-1}$ stems ha-1 (3 $\times 3 \mathrm{~m}$ spacings), and at a lesser density of 833 stems ha ${ }^{-1}$ ( $4 \times 3 \mathrm{~m}$ spacing), several different regressions were tested. For regressions based on root radius and root area measurements of excavated trees, both linear and logarithmic regressions produced identical $P$ values, as did these regressions based on the measurement of the crowns of trees within PSPs (Appendix Table A2). A linear regression has the added benefit of being useful for predicting when canopy closure and root occupancy are likely to occur.

\section{Results}

\section{Changes in PSP planting density}

An independent count of the number of mānuka planted in 2012 showed that plantings varied between 900 and 1300 stems $^{-1}$ across different parts of the landscape, and overall $15 \%$ of plantings were missing and deemed to have died within a year (pers. comm. James Powrie). As at 2015 , and based on the proportion of live to missing trees from within PSPs, the number of trees missing 3 years after planting (also presumed to have died subsequent to establishment) varied between $9 \%$ on interfluve, $16 \%$ on colluvial slopes, and $36 \%$ on areas affected by landslides. By 2018 (6 years after planting), 10\% of trees were missing from within PSPs located on interfluves, $25 \%$ on colluvial slopes, with the greatest increase of up to $45 \%$ of plants missing from PSPs located on landslideaffected slopes. However, due to the large variability in missing trees across the different landforms, confounded more by large variations in the initial planting spacing both across the different landforms and among PSPs located on the same landform, than by the proportion of trees presumed to have died subsequent to planting, no significant difference in planting density between the landforms 6 years after planting was found.

\section{Above-ground metrics and biomass}

Averaged across all 3 landforms, 46\% of mānuka were single-stemmed plants; the remainder were multistemmed. Other than for tree height, DBH, RCD, canopy diameter, and AGB did not increase significantly between 3 and 4 years after planting, nor were these metrics significantly different between plantings of the same age among landform types. However, while these metrics for mānuka plantings on interfluves increased significantly between 4 and 6 years after planting, for plantings on landslides they were not significantly different from that measured 4 years after planting (Table 4 ).

For manuka destructively sampled 3 years after planting, the allocation of total AGB to stem, branches, and foliage was initially greater to branches than stems, and least to foliage. For mānuka sampled 4 and 6 years after planting, as tree height increased, most biomass was allocated to stem, and least to foliage. These trends were independent of mānuka age and landform type (Table 6).

\section{Below-ground metrics and biomass}

The mean maximum root spread (diameter of intact root system) of mānuka excavated 3 and 4 years after planting was not significantly different among landforms. For plantings on interfluves, root spread increased from $1.4 \mathrm{~m} 3$ years after planting to $2.8 \mathrm{~m}$ a year later, and over the same period the root spread of plantings on colluvial slopes increased from 1 to $2.3 \mathrm{~m}$. By contrast, the root spread of plantings excavated on landslide sites increased minimally from 1.1 to $1.2 \mathrm{~m}$ (Table 7). Six years after planting, the root spread of mānuka on interfluves was significantly greater $(4.8 \pm 1.3 \mathrm{~m})$ than on landslides $(0.8 \pm 0.3 \mathrm{~m})$ (Table 7).

Three years after planting, the maximum rooting depth of mānuka excavated from interfluves and landslides was similar $(0.4 \mathrm{~m})$ and twice that on colluvial slopes $(0.2$ m) (Table 7). Mānuka excavated on interfluves 4 years after planting showed a significant incremental change in root depth to $0.8 \mathrm{~m}$, compared with equivalent-aged plants excavated on colluvial slopes $(0.5 \mathrm{~m})$, while root depth of plantings on landslide-affected slopes remained unchanged $(0.4 \mathrm{~m})$ (Table 7$)$. When excavated 6 years after planting, mānuka roots on interfluves penetrated deepest, reaching a maximum depth of $1.0 \mathrm{~m}$. Despite few physical limitations to root growth, their horizontal and vertical distribution was nonetheless highly asymmetric, leaving large areas of soil devoid of any roots. Six years after planting, the maximum root depth of mānuka on landslide-affected slopes was restricted to a depth of 0.5 $\mathrm{m}$ (Table 7). Minimal residual soil cover, and the presence of significant areas of exposed bedrock substrate at a shallow depth, severely limited root development on these sites. 
TABLE 6: Mean foliage, branch, stem, and seed biomass for mānuka excavated from interfluves, landslides and colluvial slopes 3 and 4 years after planting, and from interfluves and landslides 6 years after planting, Lake Tutira, northern Hawke's Bay, New Zealand.

\begin{tabular}{lrrrr}
\hline Landform/age & \multicolumn{4}{c}{ Component biomass (g) } \\
\cline { 2 - 5 } & \multicolumn{1}{c}{ Foliage } & Branches & \multicolumn{1}{l}{ Stem } & Capsules \& Seed \\
\hline Interfluves & & & & \\
3 years & $261(118) a$ & $702(465) \mathrm{a}$ & $435(202) \mathrm{a}$ & - \\
4 years & $549(301) \mathrm{a}$ & $643(291) \mathrm{a}$ & $1334(784) \mathrm{a}$ & $70(25) \mathrm{a}$ \\
6 years & $2821(1345) \mathrm{b}$ & $6988(3530) \mathrm{b}$ & $7644(1845) \mathrm{b}$ & $1275(566) \mathrm{b}$ \\
Landslides & & & & \\
3 years & $303(168) \mathrm{a}$ & $781(495) \mathrm{a}$ & $312(177) \mathrm{a}$ & \\
4 years & $240(160) \mathrm{a}$ & $357(267) \mathrm{a}$ & $556(435) \mathrm{a}$ & \\
6 years & $83(11) \mathrm{a}$ & $129(7) \mathrm{a}$ & $296(109) \mathrm{a}$ & $50(9) \mathrm{a}$ \\
Colluvial slopes & & & & \\
3 years & $130(55) \mathrm{a}$ & $349(164) \mathrm{a}$ & $295(122) \mathrm{a}$ & $10(10) \mathrm{a}$ \\
4 years & $562(370) \mathrm{a}$ & $795(545) \mathrm{a}$ & $1195(772) \mathrm{a}$ & $40(40) \mathrm{a}$ \\
\hline
\end{tabular}

Values in brackets represent the standard error of the mean, where for mānuka excavated 3 and 4 years after planting $n=3$, and for mänuka excavated 6 years after planting $n=2$. Values with different letters, within each parameter were significantly different $(P<0.05)$. Note that no mānuka were excavated from colluvial slopes 6 years after planting.

Throughout the measurement period the bulk of mānuka root biomass and length planted on all three landforms was confined to within $0.5 \mathrm{~m}$ of the ground surface. For the largest mānuka root systems excavated on interfluves 6 years after planting, $4 \%$ only of the total root biomass, and $5 \%$ only of the total root length was located below $0.5 \mathrm{~m}$ depth. Mānuka plantings on landslides had no roots below this depth. Thus, 6 years after planting there was insufficient root mass below the basal shear plane (depth of $\sim 1 \mathrm{~m}$ ) to anchor the soil to the underlying substrate.

The mean total root length of mānuka plantings excavated from each landform type 3 and 4 years after planting was not significantly different but when excavated 6 years after planting those excavated from interfluves had a mean total root length of $161 \mathrm{~m}$, greatly exceeding that of mānuka excavated from landslides (14 m). The mean total root length of mānuka plantings excavated from landslides 6 years after planting was significantly less than for plants excavated from colluvial slopes (30 m) 2 years earlier (Table 7).

The BGB of mānuka plantings excavated on each landform type 3 and 4 years after planting were not significantly different, but when excavated 6 years after planting, the BGB of mānuka excavated from interfluves (3401 g) was significantly greater than that of mānuka excavated from landslides (137 g) (Table 7). There were no significant differences in the root:shoot ratio among ages or landform types (Table 7).

The distribution of BGB to the root systems of mānuka plantings excavated on interfluves and landslides 4 and 6 years after planting, respectively, was apportioned equally between roots and the root bole. However, for mānuka excavated 6 years after planting, the plantings on interfluves had accumulated $97 \%$ more root biomass and $94 \%$ more root bole biomass than had plantings on landslides of which the largest proportion (68\%) was allocated to root biomass, and $32 \%$ to the root bole (Table 8).

\section{Root length distribution by radial distance and root diameter size class}

Irrespective of distance from the root bole, the length of structural roots $(>1 \mathrm{~mm})$ present within each 0.5 $m$ radial increment was not statistically significantly different across age classes or landforms (Table 9).

Regardless of landform type, $100 \%$ of the total length of structural roots ( $>1 \mathrm{~mm}$ ) of mānuka excavated 3 years after planting was confined to within $1.0 \mathrm{~m}$ of the root bole. Four years after planting, the proportion of the total root length of plantings excavated from interfluves and colluvial slopes, and present at between 1.5 and $2.0 \mathrm{~m}$ radius of the root bole ( $2.6 \%$ and $0.6 \%$, respectively), was not significantly different between these landforms. Six years after planting, mānuka established on interfluves had developed structural roots to a radial distance of between 2.5 and $3.0 \mathrm{~m}$ where they comprised $0.2 \%$ only of the total root length. In contrast, structural roots of equivalent-aged mānuka plantings on landslides were absent beyond $1.5 \mathrm{~m}$ of the root bole (Fig. 4; Table 9).

Irrespective of landform type, the year root systems were excavated, or distance from the root bole, roots in the 1-2 $\mathrm{mm}$ and 2-5 mm diameter size classes made up the greatest proportion of the total length of structural roots within each $0.5 \mathrm{~m}$ radial segment (Fig. 4). For mānuka excavated 3 and 4 years after planting, structural roots in the 5-10 and 10-20 mm diameter size classes remained largely confined to within a $0.5-\mathrm{m}$ radius of the root bole. 
TABLE 7: Mean below-ground growth metrics for mānuka excavated from interfluves, landslides and colluvial slopes 3 and 4 years after planting, and from interfluves and landslides 6 years after planting, Lake Tutira, northern Hawke's Bay, New Zealand.

\begin{tabular}{|c|c|c|c|c|c|}
\hline Landforms \& age & Root spread (m) & Root depth (m) & Root length (m) & Total BGB (g) & Root:shoot ratio \\
\hline \multicolumn{6}{|l|}{ Interfluves } \\
\hline 3 years & $1.4(0.4) \mathrm{a}$ & $0.4(0.1) \mathrm{a}$ & 47 (3)a & 278 (145)a & $0.18(0.04) \mathrm{a}$ \\
\hline 4 years & $2.8(0.4) \mathrm{a}$ & $0.8(0.1) b$ & $45(22) a$ & 543 (330)a & $0.19(0.02) \mathrm{a}$ \\
\hline 6 years & $4.8(1.3) b$ & $1.0(0.0) c$ & $161(55) \mathrm{b}$ & 3401 (1197)b & $0.18(0.01) a$ \\
\hline \multicolumn{6}{|l|}{ Landslides } \\
\hline 3 years & $1.1(0.2) \mathrm{a}$ & $0.4(0.2) a$ & $19(12) a$ & 213 (131)a & $0.14(0.02) \mathrm{a}$ \\
\hline 4 years & $1.2(0.5) \mathrm{a}$ & $0.4(0.1) \mathrm{a}$ & $24(16) a$ & 185 (132)a & $0.18(0.02) a$ \\
\hline 6 years & $0.8(0.3) \mathrm{a}$ & $0.5(0.1) \mathrm{a}$ & $14(4) a$ & 137 (39)a & $0.24(0.03) a$ \\
\hline \multicolumn{6}{|l|}{ Colluvial slopes } \\
\hline 3 years & $1.0(0.3) \mathrm{a}$ & $0.2(0.1) \mathrm{a}$ & 13 (5)a & $129(63) a$ & $0.16(0.01) a$ \\
\hline 4 years & $2.3(0.4) \mathrm{a}$ & $0.5(0.1) \mathrm{a}$ & $30(17) a$ & 398 (308)a & $0.15(0.03) a$ \\
\hline
\end{tabular}

Values in brackets represent the standard error of the mean, where for mānuka excavated 3 and 4 years after planting $n=3$, and for mänuka excavated 6 years after planting $n=2$. Values with different letters, within each parameter were significantly different $(P<0.05)$. Note that no mānuka were excavated from colluvial slopes 6 years after planting.

Although the root systems of mānuka excavated from interfluves 6 years after planting comprised 20-50 mm diameter roots, they made up just $1.4 \%$ of the total root length and were confined to within a $0.5-\mathrm{m}$ radius of the root bole (Fig. 4). In contrast, roots greater than 10-20 $\mathrm{mm}$ were absent from the more compact and shallowerrooted mānuka plantings excavated from landslides.
Root biomass distribution by radial distance and root diameter size class

Irrespective of landform, and for each measurement period, $\geq 74-100 \%$ of the total root biomass was confined to within $0.5 \mathrm{~m}$ of the root bole, and $94-100 \%$ remained confined within a 1-m radius (Table 10). Only for mānuka excavated from interfluves 6 years after planting was

TABLE 8: Mean root and root bole biomass (g), as a percentage of total below-ground biomass (BGB) for mānuka excavated from interfluves, landslides and colluvial slopes 3 and 4 years after planting, and from interfluves and landslides 6 years after planting, Lake Tutira, northern Hawke's Bay, New Zealand.

\begin{tabular}{lllllll}
\hline Landform & Biomass (g) & & \multicolumn{5}{c}{ \%BGB } \\
\hline & Year 3 & Year 4 & Year 6 & Year 3 & Year 4 & Year 6 \\
Root & & & & & & \\
Interfluves & $168.6(90.3) \mathrm{a}$ & $360.4(207.6) \mathrm{a}$ & $2273.2(710.4) \mathrm{b}$ & $58.9(1.8) \mathrm{a}$ & $68.2(3.3) \mathrm{ab}$ & $67.9(3.0) \mathrm{ab}$ \\
Landslide & $126.1(78.6) \mathrm{a}$ & $89.5(62.4) \mathrm{a}$ & $69.1(22.2) \mathrm{a}$ & $57.2(2.4) \mathrm{a}$ & $50.0(5.7) \mathrm{a}$ & $50.0(2.1) \mathrm{a}$ \\
Colluvial & $61.6(26.8) \mathrm{a}$ & $187.7(136.3) \mathrm{a}$ & - & $50.9(3.7) \mathrm{a}$ & $51.1(5.0) \mathrm{a}$ & - \\
Root bole & & & & & & \\
Interfluves & $109.2(54.7) \mathrm{a}$ & $182.7(122.5) \mathrm{a}$ & $1127.5(486.9) \mathrm{b}$ & $41.1(1.8) \mathrm{ab}$ & $31.8(3.3) \mathrm{a}$ & $32.1(3.0) \mathrm{a}$ \\
Landslide & $86.6(51.9) \mathrm{a}$ & $95.9(693.3) \mathrm{a}$ & $67.5(16.4) \mathrm{a}$ & $42.8(2.4) \mathrm{ab}$ & $50.0(5.7) \mathrm{b}$ & $50.0(2.1) \mathrm{b}$ \\
Colluvial & $67.2(36.3) \mathrm{a}$ & $210.3(172.2) \mathrm{a}$ & - & $49.1(3.7) \mathrm{b}$ & $48.9(5.0) \mathrm{b}$ & - \\
\hline
\end{tabular}

Values in brackets represent the standard error of the mean, where for mānuka excavated 3 and 4 years after planting $n=3$, and for mānuka excavated 6 years after planting $n=2$. Values with different letters, within each parameter, were significantly different (P<0.05). Note: No mänuka were excavated from colluvial slopes 6 years after planting. 


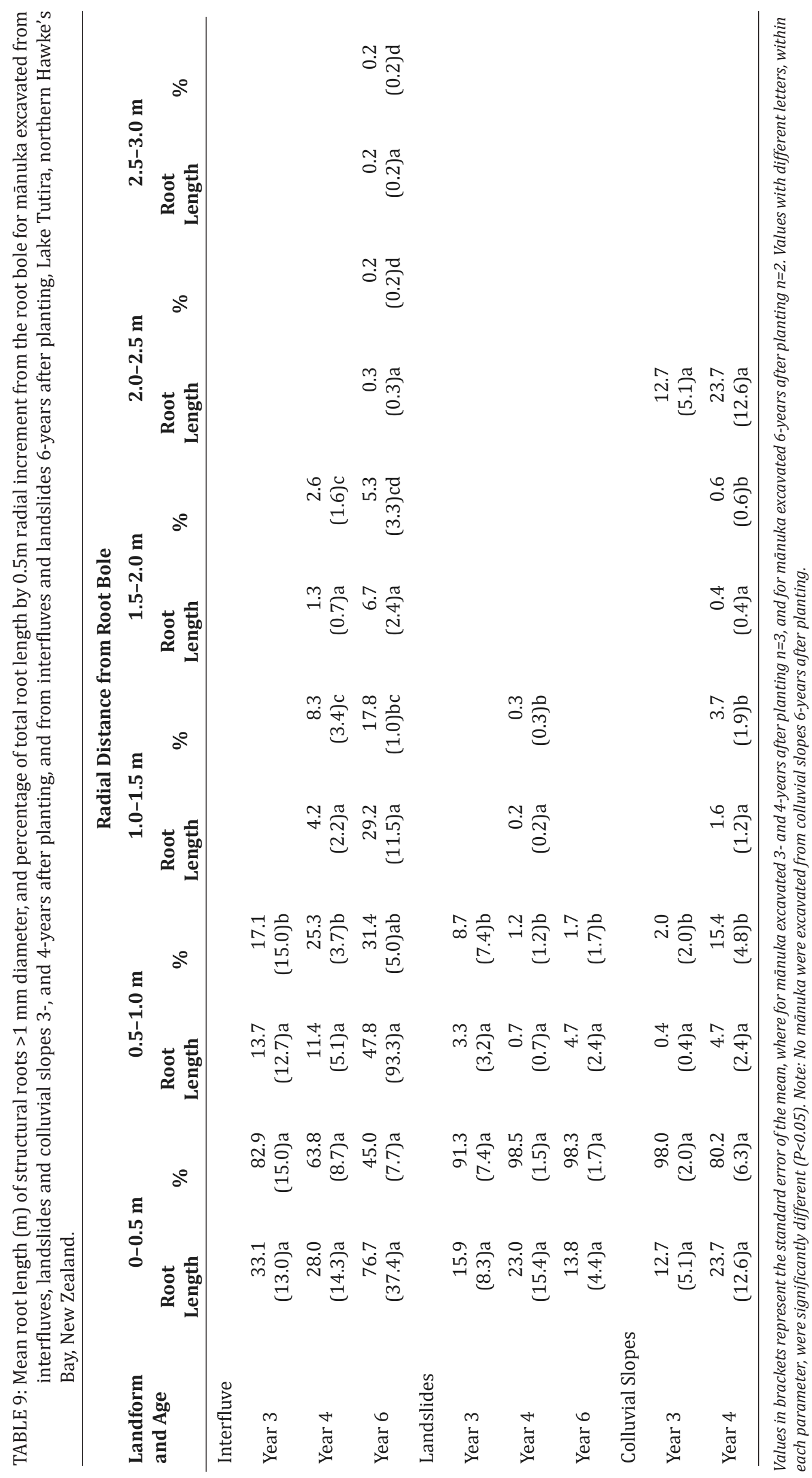



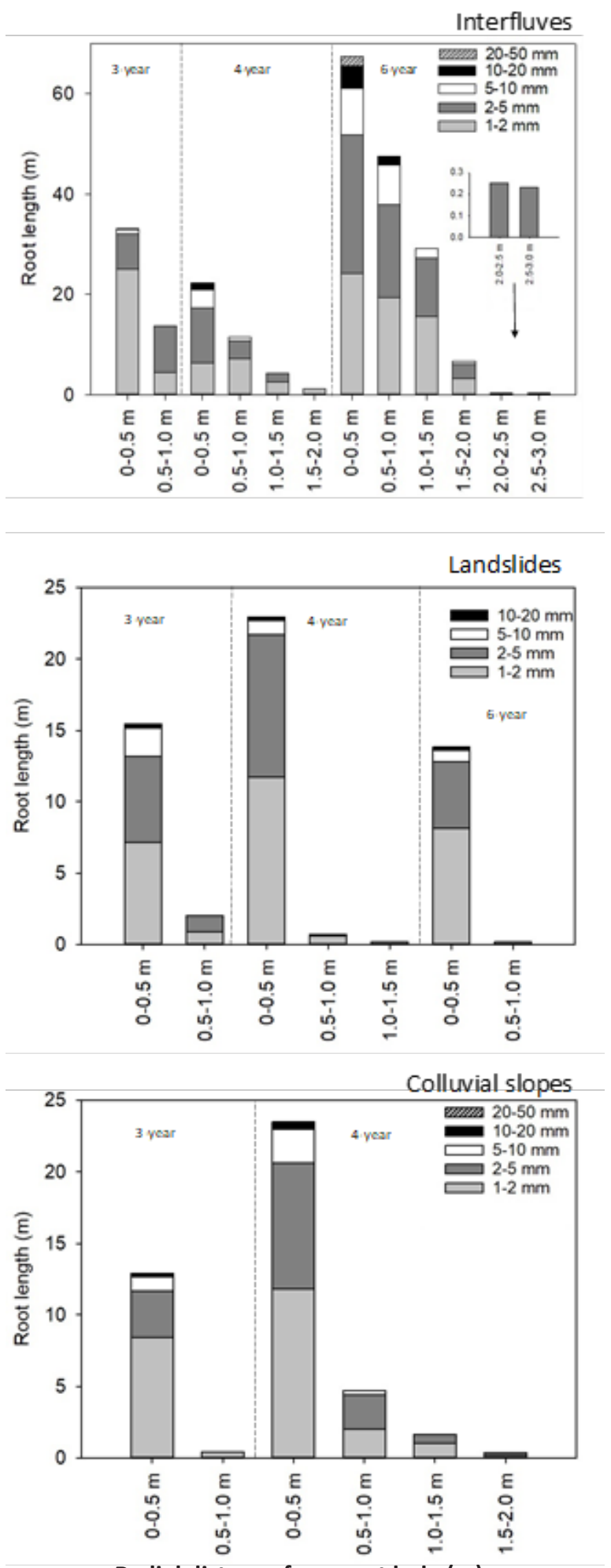

Radial distance from root bole $(\mathrm{m})$

FIGURE 4: Root length, by diameter size class, in $0.5 \mathrm{~m}$ radial segments from the root bole for mānuka excavated from interfluves, landslides and colluvial slopes at Lake Tutira, northern Hawke's Bay, New Zealand. For mānuka excavated 3 and 4 years after planting $n=3$, and for mānuka excavated 6 years after planting $n=2$. Note the scale difference for roots beyond a $2.0-\mathrm{m}$ radial distance of the root bole, and that no mānuka were excavated from colluvial slopes 6 years after planting. root biomass present beyond a $1.5-\mathrm{m}$ radius decreasing by an order of magnitude to $1.2 \%$, and beyond a $2.0 \mathrm{~m}$ radius to $0.2 \%$ of total root biomass (Table 10 ). Although not statistically significant beyond a $0.5-\mathrm{m}$ radius of the root bole, the proportion of total root biomass allocated to the smaller root diameter sizes, as the lateral roots branched and tapered to smaller diameters, decreased with increasing distance from the root bole (Table 10).

Mānuka excavated across all landform types 3 and 4 years after planting exhibited an increase in root biomass allocation towards larger diameter roots and was relatively well-distributed between each of the root diameter size classes $>2 \mathrm{~mm}$ (Fig. 5). Root biomass distribution by diameter size class for mānuka excavated from interfluves 6 years after planting was predominantly allocated to roots in the $5-10 \mathrm{~mm}, 10-20 \mathrm{~mm}$, and $20-$ $50 \mathrm{~mm}$ diameter size classes, of which the larger 20-50 $\mathrm{mm}$ roots comprised $37 \%$ (range $27-46 \%$ ) of the total root biomass, while roots $<2 \mathrm{~mm}$ in diameter (including fibrous) accounted for only $10 \%$ (range $10-11 \%$ ) of the total root biomass. By contrast, the root biomass of the more compact and shallower root systems of mānuka excavated from landslides 6 years after planting had no roots $>20 \mathrm{~mm}$ in diameter and instead was dominated by roots $<2 \mathrm{~mm}$ in diameter accounting for $31 \%$ (range $26-36 \%$ ) of their total root biomass.

\section{Allometry}

Two parameter exponential regressions of RCD against foliage, branch, and stem biomass, total AGB, total BGB, and total root biomass produced a good fit, with RCD explaining between 92 and 99\% of the variation in mānuka biomass. This analysis, however, produced a poor fit for root length, with RCD explaining only 64\% of the variation in total root length (Fig. 6). The larger mānuka plants excavated from interfluves 6 years after planting appear to be driving the fit of the regression curves. Power analysis of RCD against the height of mānuka 3, 4, and 6 years after planting was a good fit for both the excavated plants $\left(r^{2}=0.82\right)$ (Fig. $\left.7 a\right)$ and for mānuka plantings contained within the bounds of PSPs located on each landform (range $\mathrm{r}^{2}=0.64-0.78$ ). (Fig. 7b). While RCD explained $64 \%$ and $66 \%$ of the respective variation in mānuka height for plantings on interfluves and landslides, RCD produced a better fit for mānuka on colluvial slopes $\left(r^{2}=0.78\right)$ (Table 5).

\section{Modelled rate of canopy closure and soil-root occupancy}

Based on incremental changes in the crown diameter of mānuka within PSPs, canopy closure of plantings on each of the landforms is predicted to occur at different times (years elapsed since planting) (Fig. 8). At an even spacing of $3 \times 3 \mathrm{~m}$ (1111 stems ha ${ }^{-1}$ ), the crowns of mānuka plantings on colluvial slopes would attain canopy closure earliest at 6.5 years after planting, after 8 years on interfluves, and after 9.5 years on landslides. By comparison, for less-dense plantings established at an uneven spacing of $4 \times 3 \mathrm{~m}$ (833 stems ha-1), canopy closure across the wider, 4-m gap between planted rows would likely be delayed until 8 years after planting on 


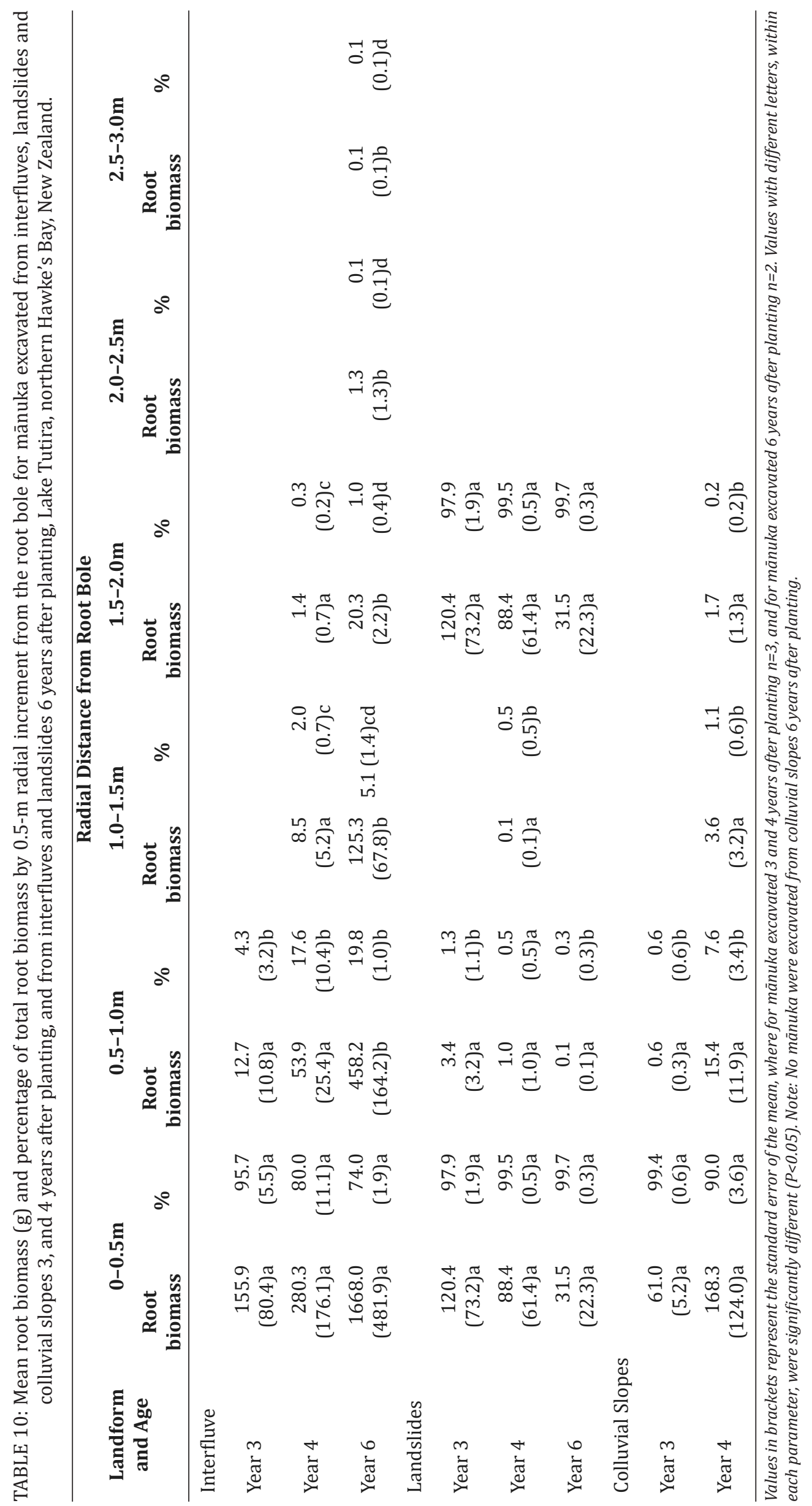



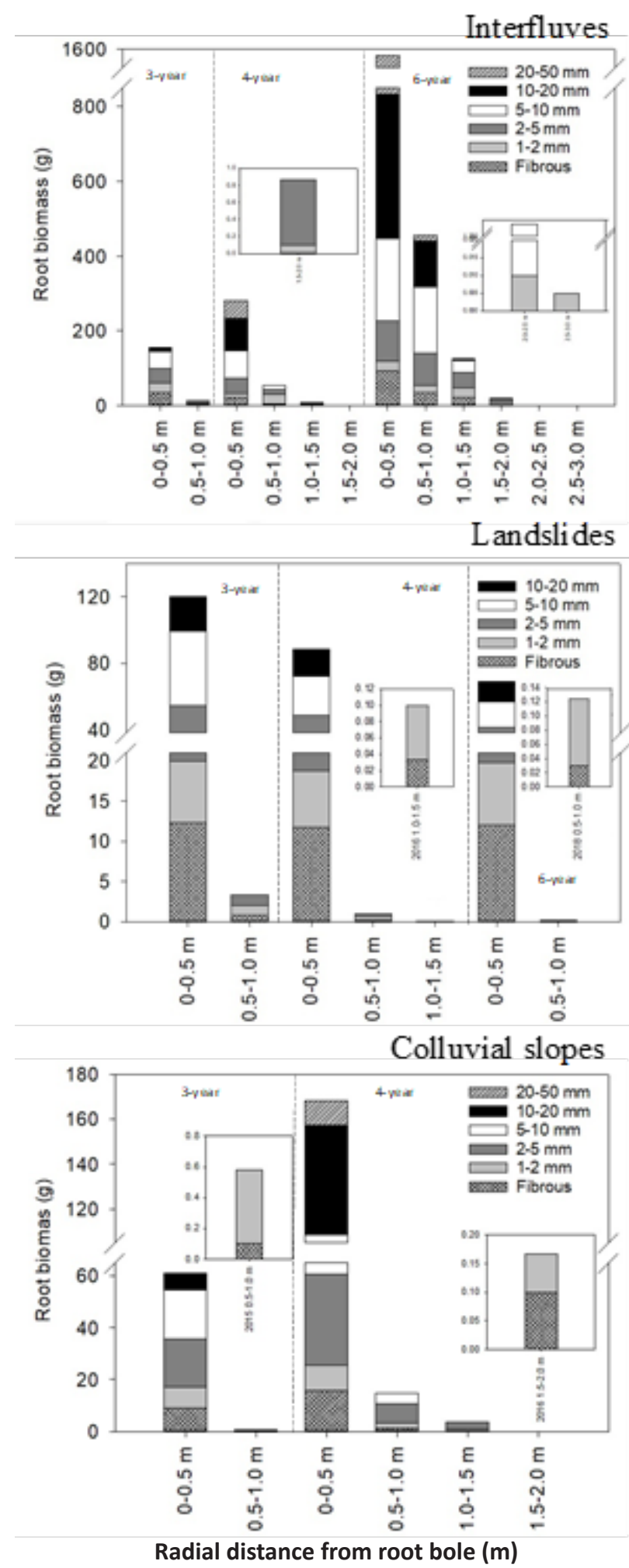

FIGURE 5: Root biomass distribution, by root diameter size class, in 0.5-m radial segments from the root bole for mānuka plants excavated from interfluves, landslides and colluvial slopes at Lake Tutira, northern Hawke's Bay, New Zealand. For mānuka excavated 3 and 4 years after planting $n=3$, and for mānuka excavated 6 years after planting $n=2$. Note the scale difference for roots beyond a $2.0-\mathrm{m}$ distance from the root bole, and that no mānuka were excavated from colluvial slopes 6 years after planting. colluvial slopes, after 11 years on interfluves, and on landslides for $>12$ years after planting.

Based on the mean root spread (diameter) of root systems excavated from each landform, root occupancy for plantings on colluvial slopes and interfluves at an even spacing of $3 \times 3 \mathrm{~m}$ (1111 stems ha-1) would occur 4-4.5 years after planting (Fig. 9). Conversely, with a maximum root radius of just $0.5 \mathrm{~m}$ after 6 years, root occupancy for planting on landslide-scarred slopes had still to occur. At a less-dense (833 stems $\mathrm{ha}^{-1}$ ) planting regime where plantings are unevenly spaced $(4 \times 3 \mathrm{~m}$ spacing), lateral root extension across the wider 4-m gap between planted rows would likely be further delayed until between 5 and 6 years after planting on both colluvial slopes and interfluves, while full root occupancy may not occur at all on slopes that have been extensively scarred by landslides.

\section{Discussion}

Tree canopies have been shown to play a significant role in lessening the initiation of shallow slope failures through interception (Kelliher et al. 1992) and transpiration (Pearce et al. 1987). A relationship also exists between rainfall intensity/duration, landslide density, and vegetation type and maturity (Selby 1976; Salter et al. 1973), even though the relative amount of rainfall intercepted during extreme rainfall events is small (Blake 1965; Aldridge \& Jackson 1968, 1973; Jackson \& Aldridge 1973; Rowe et al. 1999). Furthermore, while young vegetation during the initial years after establishment affords little protection against the initiation of landslides in the event of a major storm, the reduction in storm-initiated slope failures is significant once canopy closure of forest and shrubland species had been attained (Marden \& Rowan 1993). For example, while the occurrence of landslides initiated in the East Coast Region of the North Island during a major storm in 1988 (Cyclone Bola) that delivered $23 \mathrm{~mm} / \mathrm{hr}$ and $917 \mathrm{~mm}$ in the 72-h storm duration was greatest in areas that received the most rainfall, their incidence (density) in areas of well-established, closed-canopied naturally regenerating mānuka and kānuka shrubland was significantly less than in adjacent areas under pasture (Bergin et al. 1995; Marden et al. 1995).

The mechanical reinforcement of soil by roots (Watson et al. 1999) also contributes to improved land stability. Thus, options that promote full soil-root reinforcement the fastest are likely to be the most effective in enhancing slope stability (Phillips et al. 2001). As the mean maximum root spread (Table 7) of excavated mānuka on interfluve and colluvial slopes in each year of the trial exceeded crown widths of both the excavated trees and those measured in PSPs (Table 4), root occupancy of the soil might be expected to occur in advance of canopy closure on these landforms. Conversely, although the maximum root spread for mānuka excavated from landslide-affected slopes was also greater than their crown width, their significantly smaller dimension suggests that lateral root reinforcement of the soil would be expected to take longer than on other landforms where conditions were more conducive to root development. 

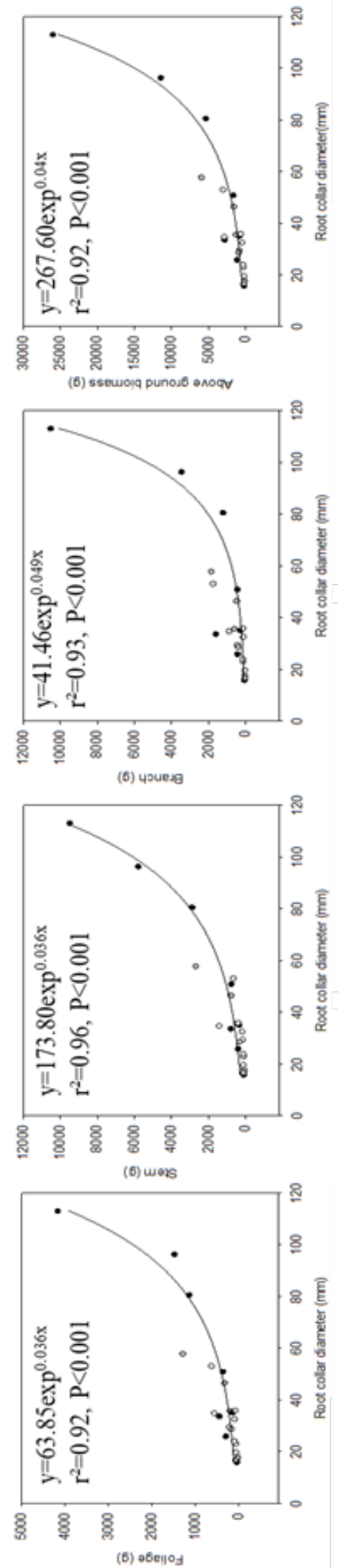

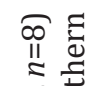

䗢

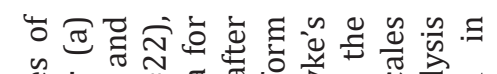

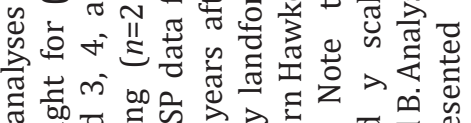

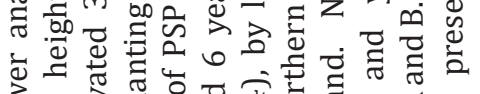

\&

$\exists$ ōo

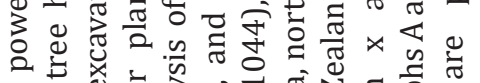

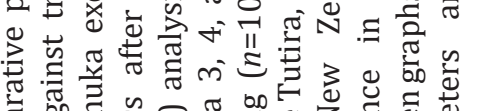

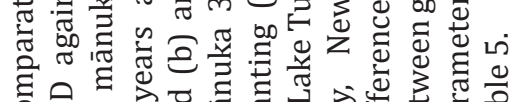

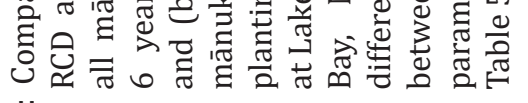
$\ddot{n}$

罩
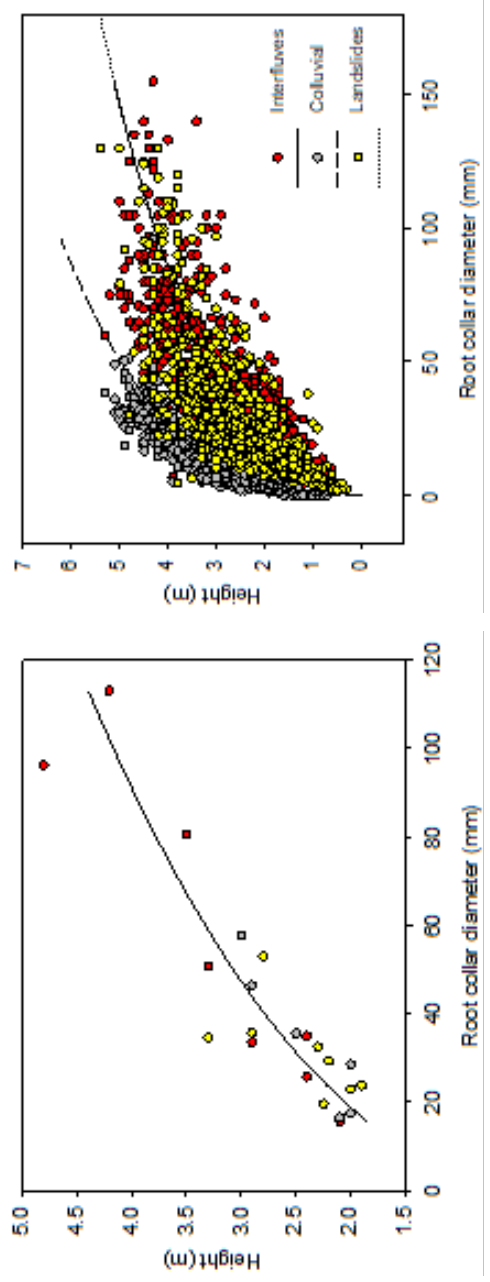


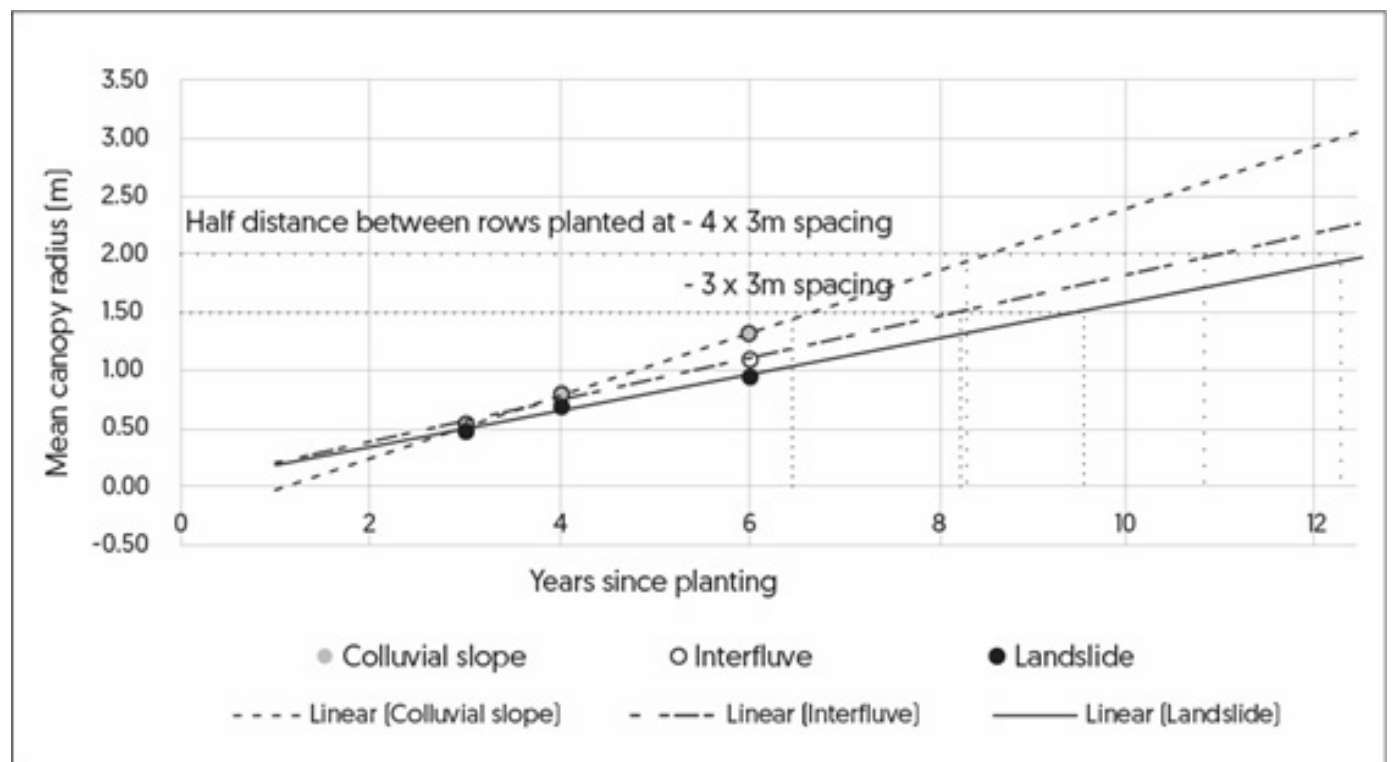

FIGURE 8: Mean canopy radius of mānuka within PSPs established on each landform 3, 4, and 6 years after planting, Lake Tūtira, northern Hawke's Bay, New Zealand. Vertical dotted lines indicate the approximate time required for the canopy of individual mānuka to occupy half the distance between rows planted $3 \mathrm{~m}$ (1111 stems ha-1), and $4 \mathrm{~m}$ (833 stems ha ${ }^{-1}$ ) apart to attain canopy closure.

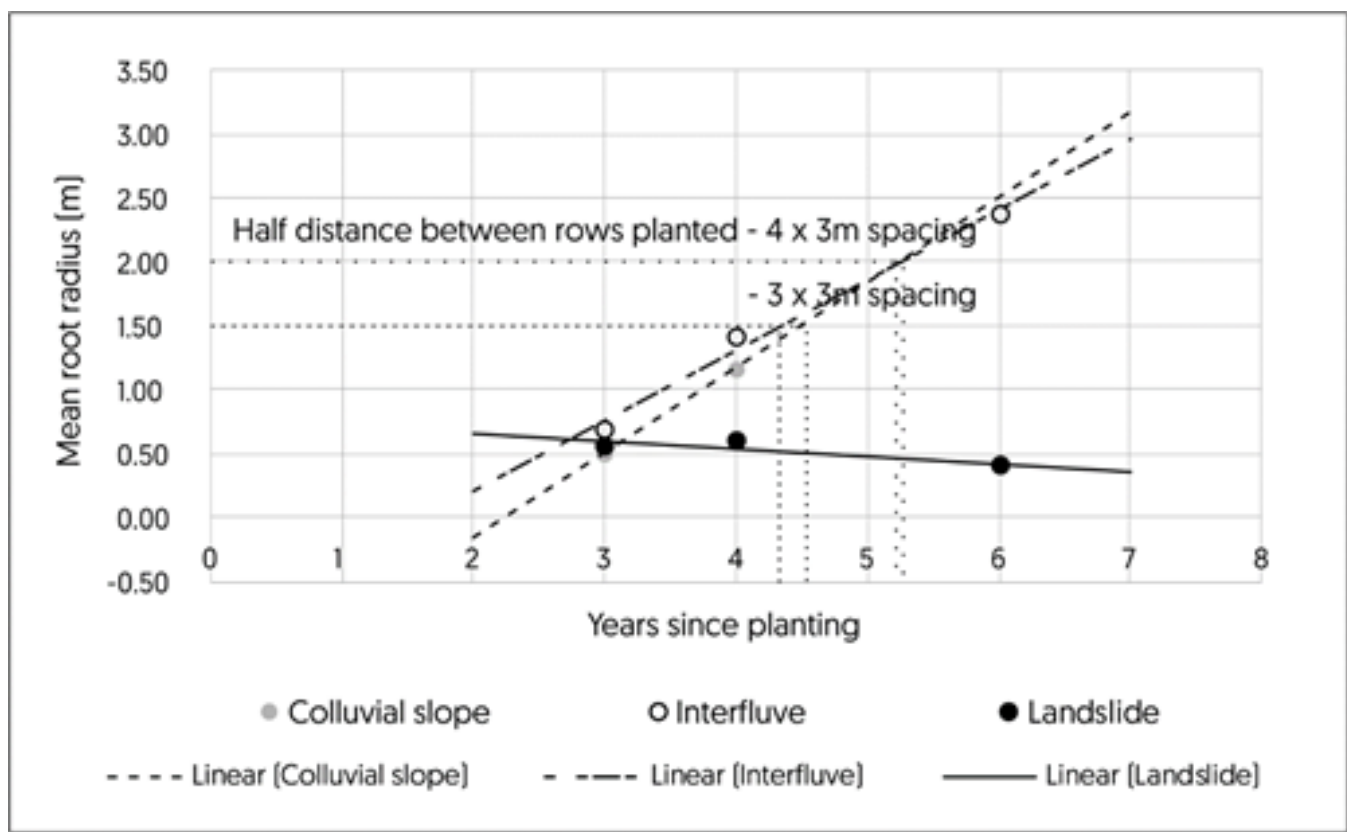

FIGURE 9: Mean root radius of mānuka excavated from each landform 3 and 4 years after planting, and from interfluves and landslide-affected sites 6 years after planting, Lake Tūtira, northern Hawke's Bay, New Zealand. Note that no mānuka were excavated from colluvial slopes 6 years after planting. Vertical dotted lines indicate approximate time required by roots of individual mānuka to occupy the soil at half the distance between rows planted $3 \mathrm{~m}$ (1111 stems ha-1), and $4 \mathrm{~m}\left(833\right.$ stems ha-1 $^{-1}$ ) apart to attain canopy closure.

However, roots are also the means by which trees extract moisture from the soil to grow, resulting in reduced pore-water pressures (Ekanayake et al. 1997). Thus, at the time when canopy closure (crowns of individual trees touch) and full root occupancy (lateral roots of adjacent trees overlap) first occur, their combined soilroot reinforcement and hydrological influences become most effective in the prevention of shallow landslides (Kelliher et al. 1992).
The study site has a climate considered near optimal for mānuka growth (McPherson \& Newstrom-Lloyd 2018). Here, the growth of low-density mānuka plantings has also been influenced by differences in physical and chemical site factors across the different landforms with incremental change, above- and below-ground, being greatest on both the naturally fertile interfluves and colluvial slopes. On interfluves where the allophanic soil profiles are deep, and—on both landforms—-where soils 
are well-aerated, mānuka plantings have access to large soil moisture and nutrient reserves (Scholten et al. 2017; Yost et al. 2018), allowing for greater, and earlier root development. Despite few physical limitations to root growth, their horizontal and vertical distribution was nonetheless highly asymmetric leaving large areas of soil devoid of any roots. This was particularly noticeable on colluvial slopes where roots followed paths of least resistance between broken and upturned earth sods with concentrations of fine root mass development occurring in pockets of buried soil rich in organic matter.

In contrast, for mānuka planted on predominantly steeper, landslide-impacted slopes, the potential for root development was likely limited by the presence of skeletal and shallow soils with limited potential for retaining soil moisture during lengthy dry spells. Typically, and as a response to the harsh site conditions, root systems are more compact and tend to be dominated by smaller diameter roots to form a dense network particularly of fibrous roots. In addition, impenetrable bedrock at shallow depths further restricts root development, particularly of vertical roots, therefore the overall growth performance of mānuka plantings on slopes impacted by landslides is significantly less than of plantings of equivalent age established on interfluves and colluvial slopes. Thus, differences in the availability of nutrients and water, together with contrasting site factors (e.g. location in the landscape, sheltered versus exposed sites, soil depth to bedrock etc.), and variable planting spacing likely explains much of the variation in mānuka growth form across the different landforms. An unknown factor is the influence of the genetics of the parent mānuka from which the seedlings were grown.

Published accounts on the architecture of mānuka root systems, particularly of juvenile mānuka, are rare, largely descriptive (Watson \& O'Loughlin 1985; Marden et al. 2005) and with little quantitative or photographic data available. As previously described in Marden et al. (2005) using the descriptive classification of Hinds and Reed (1957), root systems of mānuka are heart shaped. Their root systems develop a high proportion of vertical and obliquely inclined, structural-size roots $(>1 \mathrm{~mm}$ diameter) descending from or near the root bole, often striking horizontally at a relatively shallow depth and changing orientation frequently. Lateral roots develop at an early age, spreading from the tap root, or from the root bole, possibly in two or more plates or strata, often with multiple branching at their extremities. The development of a heart-shaped root architecture may indeed be an adaptation typical of early colonising species in their search for nutrients and surface water, and to provide a higher level of near-surface soil reinforcement and stability (wind firmness) at a greater distance from the stem.

Based solely on a comparison of root system dimensions (diameter) of plantings across the different landforms, mānuka plantings on interfluve and colluvial slopes developed significantly larger root systems than those established on slopes impacted by landsliding. Thus, based on the dimensions of mānuka root systems excavated 3, 4, and 6 years after planting, lateral soil- root reinforcement could be expected to occur earliest on interfluve and colluvial slopes and be more effective in mitigating the initiation of shallow landslides on similar landforms elsewhere than would mānuka at an equivalent age on landslide-impacted slopes, unless planted and maintained at higher densities.

Similar conclusions were reached in studies of root system dimensions of exotic species including alder (Alnus rubra), cypress (Cupressus lucitanica), and blackwood (Acacia melanoxylon) (Phillips et al. 2015), indigenous riparian species (Marden et al. 2005, 2018a), indigenous evergreen conifer and broadleaved forest species (Marden et al. 2018b), and radiata pine (Pinus radiata) at a similar age (Watson \& Tombleson 2002, 2004; Marden et al. 2016).

The precision of root biomass estimates for many of New Zealand's indigenous shrubland/forest species using allometric relationships between height and DBH tends to be low (Hall et al. 2001). In the absence of more reliable species-specific data these relationships have nonetheless been used to establish that root biomass comprises approximately $20 \%$ of total live plant biomass (Watson \& Tombleson 2002; Beets et al. 2007). For seedlings, however, and as has been shown by Wagner \& Ter-Mikaelian (1999), because stem taper is minimal, RCD may serve as a better predictor in the analysis of tree allometry. Although comparisons with published work on the root allometry of other juvenile New Zealand indigenous species are limited (Marden et al. 2018a, b), these studies found RCD to be a good fit for estimating total root biomass and root length with regressions being highly significant $(P<0.001)$. Similarly, as has been shown in this paper, for the indigenous species mānuka planted at Lake Tutira, allometric relationships between RCD foliage, branch, and stem biomass, total AGB, total $\mathrm{BGB}$, and total root biomass produced very good $r^{2}$ values (range 92-99\%). The regression analysis for root length, however, was a poorer fit, explaining $64 \%$ of the variation in total root length (Fig. 6).

Furthermore, Phillips et al. (2015) found it possible to develop simple relationships between RCD and root attributes of a variety of exotic forest species grown in New Zealand, with reasonable $r^{2}$ values for BGB and total root length, while Marden et al. (2016) found that two-parameter exponential regressions using RCD were successful in predicting the BGB of five seed lots of $P$. radiata excavated 1 to 4 years after planting with RCD explaining between 93 and $98 \%$ of the variability in BGB.

Currently, for many of New Zealand's most common indigenous species, the allocation of total plant biomass to BGB is largely unknown, particularly during the early years after planting, with few studies of site factors as contributing influences in the allocation of biomass to roots, its apportionment between roots and root bole, and between root diameter size classes.

The root:shoot ratio of mānuka excavated from the harshest landslide-prone sites 6-years after planting approximated $0.24 \quad( \pm 0.03)$, compared with 0.18 $( \pm 0.001)$ for mānuka established on the more fertile colluvial slopes and interfluves. This may indicate that at sites where soils are thin and skeletal and soil moisture 
availability low, more biomass is redirected towards early root development to improve accessibility to these resources (e.g., Lloreet et al. 1999). Furthermore, the current results are not dissimilar to values for five different clones of Pinus radiata (0.22) excavated 5 years after planting in similarly steep hill country (Marden et al. 2016), and are also consistent with root:shoot ratios of similar-aged pines (Pinus spp.) planted at a range of New Zealand field locations (Watson \& Tombleson 2002, 2004). These results also likely reflect harsher edaphic factors (Ketterings et al. 2001) akin to the landslideaffected parts of the Lake Tūtira study site. Conversely, on interfluves where the soils are deeper, richer in organic matter, and more physically fertile with lower drought stress, root systems develop earlier and quicker than the shoot, as was also demonstrated by the high root:shoot ratios obtained for exotic species including eucalypt (Eucalyptus fastigata) (0.33), redwood (Sequoia sempervirens) (0.29), blackwood (Acacia melanoxylon) (0.37), and Pinus radiata (0.36) excavated 3 years after planting at a fertile alluvial site (Phillips et al. 2015).

For mānuka, this study reports the first known data on the proportion of BGB apportioned to the roots versus the root bole, changes in biomass apportionment to these components with age, and biomass apportionment to different root size classes of mānuka excavated from each landform. Three years after planting, mānuka plantings on landslides allocated $57.2 \%$ of their total BGB to roots and $42.8 \%$ to the root bole, and for interfluves the allocation was $58.9 \%$ and $41.1 \%$, while on colluvial slopes this ratio was approximately equal at $50.9 \%$ and $49.1 \%$ respectively, and this difference was significant (Table 8). The early investment of BGB to roots is considered an adaptation typical of early colonising species in their search for nutrients and water, and to provide a higher level of near-surface soil reinforcement and stability (wind firmness) at a greater distance from the stem. In later years, the allocation of BGB to the roots of mānuka established on fertile interfluves was largely confined to organic-rich topsoils ( $\sim 20 \mathrm{~cm}$ thick), whereas for mānuka in search of nutrients within loosely compacted colluvium containing buried soils at deeper horizons, biomass was equally allocated to extending roots and the root bole to greater depths.

Furthermore, while mānuka plantings excavated from all three landforms 3 and 4 years after planting exhibited an increase in root biomass allocation towards larger diameter roots, and the allocation was relatively well-distributed between each of the root diameter size classes $>2 \mathrm{~mm}$, the allocation of root biomass by root size class 6 years after planting differed between landforms. For example, the root systems of mānuka excavated from interfluves 6 years after planting were dominated by roots in the $>10 \mathrm{~mm}$ size class, of which the larger 20-50 mm roots comprised 36\% (range 27-46\%) of the total root biomass, while roots $<2 \mathrm{~mm}$ in diameter accounted for only 4\% (range 3-5\%) of the total root biomass. By contrast, the root biomass of the more compact and shallower root systems of mānuka excavated from landslides 6 years after planting had no roots $>10 \mathrm{~mm}$ in diameter, and instead were dominated by fibrous $(<1 \mathrm{~mm})$ and $1-2 \mathrm{~mm}$ size roots, with those $>1<2 \mathrm{~mm}$ in diameter accounting for $17 \%$ (range 11$23 \%$ ) of their total root biomass.

As might be expected, root systems comprising the largest root biomass, length and diameter sizes form a dense membrane (Schmidt et al. 2001) that provides a higher level of soil-root reinforcement (Swanston \& Swanston 1976) closest to the root bole. For mānuka 6 years after planting on interfluves their root systems extended $2.4 \mathrm{~m}$ from the root bole, with $92.8 \%$ of the mean total root length (Table 9), and $93.8 \%$ of the total root biomass (Table 10) - the factors most commonly used to infer the potential lateral soil-reinforcing ability - occurring within $1.0 \mathrm{~m}$ of the root bole. By comparison, $100 \%$ of the root length (Table 9) and biomass (Table 10 ) of plantings on landslides was confined to within 0.5 $\mathrm{m}$ of the root bole, thus the area of potential lateral soilreinforcement for mānuka plantings on interfluves was double that of equivalent-aged plantings on landslides.

The development of a compact and dense root system close to the root bole was also observed during the excavation of several other indigenous and exotic species of similar age. These include the native conifers matai (Prumnopitys taxifolia) and miro (Prumnopitys ferruginea), the broadleaved titoki (Alectryon excelsum) (Marden et al. 2018b), and exotic species including oak (Quercus robur) and redwood (Sequoia sempervirens) (Phillips et al. 2015). Together, these studies indicate that while the root systems of juvenile plantings $\leq 6$ years after planting likely contribute significantly towards improving soil-root reinforcement, the actual area of reinforcement is largely confined to within a 0.5-1.0 m radius of the root bole, and as is common to all species, the level of lateral soil-root reinforcement rapidly decreases as the density of roots tapers off with increasing distance from the root bole.

The mechanical interactions of woody roots with the soil medium also play an important role in tree anchorage. Therefore, one of the most important traits of a root system is rooting depth, which is speciesdependent when soil conditions are not limiting. In New Zealand, the most common form of erosion occurs from landslides initiated by storms (Basher 2013). Such landslides are typically small, shallow, and translational, with failure often coinciding with a basal shear plane $\leq 1$ m depth (Marden et al. 1991; Page et al. 1994). Thus, roots must cross the basal shear plane (Wu et al. 1979) in order to anchor the soil into more stable substrate and stabilise a slope against the initiation of shallow landslides. The entire root systems of mānuka excavated 6 years after planting on interfluve slopes were confined to within the top $1.0 \mathrm{~m}$ of regolith, and for plantings established on landslide-scarred slopes to the top $0.5 \mathrm{~m}$. For many other juvenile indigenous species at a similar age, the lack of roots extending to the depth of the basal shear plane is not atypical (Watson et al. 1995; Marden et al. 2005, 2018a, b). The absence of structural roots ( $>2 \mathrm{~mm}$ ) with the potential to provide reinforcement across the basal shear plane (Clark et al. 2008) suggests that new plantings of these species, including mānuka, are unlikely to prevent the occurrence of shallow 
slope failure within 6 years of planting. However, as has previously been shown, in the absence of physical barriers to lateral root development and penetration, the root systems of kānuka, a genetically related early colonising species, can extend to a maximum depth of $\sim 2 \mathrm{~m}$ (Watson et al. 1995), well below the depth of most shallow landslide failures. Intuitively, in the absence of physical barriers to lateral root development and penetration it is highly likely that mānuka root systems could within 10 years provide a moderate level of anchorage, but likely not prevent the occurrence of storm-initiated shallow landslides. Conversely, in the presence of physical barriers to lateral root development and penetration, the erosion risk may only marginally improve but remain for a considerably longer period.

\section{Influence of planting density on erosion control effectiveness of low-density plantings of mānuka}

The combined benefits of hydrological influences (interception, evaporation and transpiration) and soilroot reinforcement become most effective when canopy closure (crowns of individual trees touch) and root occupancy (lateral roots of adjacent trees overlap) first occur (Kelliher et al. 1992).

A developing canopy influences the soil moisture regime largely through interception, evaporation, and transpiration, thereby reducing the potential for landslide initiation. A delay in the timing of canopy closure will reduce the effectiveness of interception loss at times when soil moisture levels are most likely to reach saturation and slopes are at greatest risk of failing. Factors influencing canopy closure include: (i) low and variable stocking density at the time of establishment; (ii) high rates of plant mortality, and slow growth rates of plantings associated with landslide-prone slopes, a consequence of factors related to site differences including thin and nutrient-poor soils and/or poor soil-moisture retention; (iii) differences in canopy form/shape, related to seed source genetics, and/or the ratio of single-stemmed to multiple-stemmed plants, with multiple-stemmed plants having a bushier and denser canopy than the narrower canopy of singlestemmed plants (Fig. 3); (iv) windthrow; (v) stem snap; (vi) borer damage causing the collapse of closely-packed, multi-stemmed plants (Marden \& Lambie 2019); (vii) mortality due to mānuka blight caused by the scale insect Eriococcus orariensis Hoy and its accompanying sooty mould Capnodium walteri Saccardo. In drier areas, such as the East Coast region, manuka blight generally appears 3-5 years after planting; and (viii) myrtle rust may affect the survival of mānuka, however, information on myrtle rust within the New Zealand context is lacking (Lambie et al. 2018). Furthermore, the rate of spread of self-sown seedlings (wildlings) of species including kānuka will also influence the timing of canopy closure, and likely the rate of interception loss. For example, at Lake Tūtira, remnants of mature kānuka present at the time mānuka was planted provided the seed source for numerous self-sown kānuka seedlings present within many of the PSPs. Although kānuka seedlings are of smaller stature, in places they outnumber mānuka two-to-one and form a significant understorey canopy, contributing to soil reinforcement.
In well-maintained stands of low-density plantings of manuka, there is little initial competition from grasses and weeds for space, or for light or nutrients at the juvenile stage of growth. Thus, individual mānuka tend to be shorter and develop bushier canopies than within fully stocked stands of naturally reverting shrubland where stem density can be several orders of magnitude greater (Bergin et al. 1995). As a result, canopy closure occurs earlier than would be expected in stands of equivalent-aged mānuka planted at low densities. For low-density plantings of mānuka established at an even spacing of $3 \times 3 \mathrm{~m}$ (1111 stems ha ${ }^{-1}$ ), increments in crown diameter measured 3, 4, and 6 years after planting indicate that canopy closure would occur earliest on colluvial slopes ( $11.5 \%$ of study area) within about 6.5 years of planting, within 8 years on interfluves (53\% of study area), and probably not within 9.5 years after planting landslide-affected slopes $(27.4 \%$ of study area) (Fig. 8). By comparison, for plantings established at an uneven spacing of $4 \times 3 \mathrm{~m}$ (833 stems ha-1), canopy closure across the wider $4 \mathrm{~m}$ gap between rows is unlikely to occur on colluvial slopes before year 8, before year 11 on interfluves, and before $>12$ years after planting landslide-affected slopes should canopy growth rates continue in a linear form.

Increments in the spread of lateral roots (i.e. changes in the diameter of individual mānuka root systems) were highly variable across the different landforms. Four years after planting, the roots of plantings established at $3 \times 3 \mathrm{~m}$ spacings on interfluves and colluvial landforms were found to be present at a radius of $1.5 \mathrm{~m}$ (half the distance between rows) and probably overlapped with the root systems of adjacent plants (Fig. 9); 6 years after planting, roots extended to a radius of $2.4 \mathrm{~m}$. However, the proportion of total root length (7\%) and root biomass $(1 \%)$ beyond the midpoint between rows remained extremely low. By comparison, at a lower planting density of 833 stems ha ${ }^{-1}$ ( $4 \times 3 \mathrm{~m}$ spacing), and irrespective of landform type, by year 4 after planting there would have been no roots present at or beyond a $2-\mathrm{m}$ radius (half the distance between rows $4 \mathrm{~m}$ apart), and 6 years after planting only $0.2 \%$ of the total root length and $0.1 \%$ of total root biomass of mānuka plantings established on interfluves occurred at this radial distance. For mānuka plantings established on landslides $(27.4 \%$ of study area), where soils are shallower and skeletal, root systems exhibited a small decrease in root spread with increasing age, and 6 years after planting roots reached a span (diameter) of just $0.8 \mathrm{~m}$. Thus, both modelled planting density scenarios showed that root overlap within 6 years of planting is unlikely on those parts of slopes most affected by past episodes of landsliding.

Where soils were deepest on interfluves and colluvial slopes, the root systems of mānuka had, 6 years after planting, penetrated to a mean maximum root depth of $1.0 \mathrm{~m}$. However, the bulk of their total root biomass and most of the total root length was confined to within 0.5 $\mathrm{m}$ of the ground surface, whereas $4 \%$ only of the root biomass and $5 \%$ of the root length was located below this depth. By comparison, root penetration of plantings 
on former landslides was severely constrained by the limited thickness $(<0.45 \mathrm{~m})$ of skeletal soils overlying impenetrable bedrock.

These results suggest it unlikely that for either of the current low planting density scenarios there would be sufficient lateral root reinforcement (biomass and length) of the soil between rows, or present below the depth of a potential shear plane, to mitigate the initiation of shallow landslides for at least 10-15 years after planting. It is, therefore, in the period before canopy closure and full-root occupancy are attained, during which soils are most likely to reach saturation, that mānuka-planted slopes will remain at greatest risk to the initiation of shallow landslides.

Estimates of the timing of canopy closure and root occupancy assume that plantings were established at the prescribed spacings $(3 \times 3 \mathrm{~m})$ and that $100 \%$ of plants survived. However, the variability in initial planting densities and subsequent plant mortality has within 6 years of planting resulted in $\sim 25 \%$ fewer mānuka remaining on colluvial and interfluve slopes, and $\sim 45 \%$ fewer mānuka on slopes affected by landslides, than prescribed (1111 stems $\mathrm{ha}^{-1}$ ), thereby altering the overall spatial distribution of surviving mānuka across the different landforms. By implication, mānuka plantings established at the current prescribed rate will remain at risk to the initiation of shallow landslides for considerably longer than the modelled scenarios indicate. Furthermore, the slopes likely to be impacted most severely by landslides in the future, and remain at risk the longest, are those where mānuka establishment is likely to be the most spatially variable, and survival the poorest.

The period of risk could, however, be minimised by increasing the planting density so that the hydrological benefits of a closed canopy and soil-root reinforcement occur earlier. Doubling the current recommended planting density to $\sim 2000$ stems ha $^{-1}$ (2.5-m spacing) would, however, only increase the slope safety factor (a measure of the susceptibility of a slope subject to slope stresses to fail) sufficiently ( $\mathrm{SF}=1.2$ for a $45^{\circ}$ slope, $\mathrm{SF}=1.5$ for a $35^{\circ}$ slope) to mitigate the initiation of shallow landslides in plantings 8 years and older (Ekanayake et al. 1997). Indeed, historical accounts of the frequency of storm-initiated landslides within stands of naturally reverting shrubland of known age and density confirm that the level of mitigation increases with increasing stand age, and that the greatest improvements occur in stands with physiological ages of between 8 and 16 years (Bergin et al. 1995).

\section{Conclusions}

Guidelines for the successful establishment of mānuka and other indigenous shrub and tree species on erosionprone pastoral hill country require time-series data of their survival and growth rates, particularly of crown and root attributes. This is because, irrespective of plant species, juvenile plantings tend to remain at their most vulnerable to storm influences until canopy closure and full-soil root occupancy occur. While there is an expectation that plantings at higher densities will shorten the duration of the period of vulnerability, there remains little available data with which to assess the timing (years after planting) at which different planting density strategies are likely to afford an improved level of protection against the initiation of shallow landslides. The results from this trial suggest that for space-planted mānuka established at low densities, planting density and survival, incremental changes in canopy diameter and lateral root spread of the surviving plants, and age (years after planting) are key factors in ensuring a successful erosion mitigation outcome for erosion-prone land that is marginal for pastoral production but ideally suited to transitioning from shrubland to a permanent indigenous cover. However, the findings of this study also suggest that irrespective of landform type, and if plantings of mānuka could be maintained fully stocked at densities between 833 and 1111 stems ha ${ }^{-1}$, they would remain susceptible to landslide-related damage for longer than would naturally reverting stands at an equivalent age, and where the stem density is at least an order of magnitude greater (Hicks 1991; Marden \& Rowan 1993; Bergin et al. 1995).

As a major storm event has not occurred since the planting of mānuka at Lake Tūtira, the conclusions drawn from this study regarding the potential effectiveness of low-density plantings as a longer-term strategy for mitigating shallow landslides on erosionprone hill country have yet to be validated. It is therefore recommended that at the time canopy closure occurs, further above- and below-ground measurement data are collected from this established study site. This will not only confirm the influence of variable planting and plant mortality rates across different landforms on the duration of the period required (years after planting) for understocked plantings of mānuka established at a low-density to attain canopy closure, but will also provide a greater understanding of the contribution of mānuka roots to soil reinforcement. These are factors considered essential to resolving potential conflicts between managing mānuka for honey production without compromising its erosion control effectiveness in mitigating the initiation of shallow landslides on steep hill country likely to be targeted for future planting.

$\begin{array}{ll}\begin{array}{l}\text { List of abbreviations } \\ \text { AGB }\end{array} & \begin{array}{l}\text { above-ground biomass } \\ \text { below-ground biomass } \\ \text { BGB }\end{array} \\ \text { BP } & \text { before present } \\ \text { Can. Dia. } & \text { canopy diameter } \\ \text { diameter at breast height } \\ \text { DBH } & \text { hectares } \\ \text { ha } & \text { permanent sample plots } \\ \text { PSPs } & \text { root collar diameter } \\ \text { RCD } & \text { stems per hectare }\end{array}$

\section{Competing interests}

The authors declare that they have no competing interests. 


\section{Authors' contributions}

MM was the primary author. MM, SL and CJP undertook the fieldwork. SL compiled the data into spreadsheets, generated most of the graphs and tables, and completed the statistical analyses. All authors read and approved the manuscript.

\section{Acknowledgements}

We greatly appreciated the assistance in the field of Erica Smith, James Waddel, Stevie Smidt, Jack Smidt, Ben Douglas, Harrison Woolley, Max Paku, Connor Fitzgerald, Michaela King-Peters and Will Telford (Hawke's Bay Regional Council), Scott Bartlam (Landcare Research), Craig Elvidge (MPI), and Carla Deiana and Paolo Collu (visiting interns from Sassari University in Sardinia). Resource material (maps, photographs, etc.) was provided courtesy of James Powrie (Hawke's Bay Regional Council).

This research would not have been possible without the Hawke's Bay Regional Council and COMVITA granting permission to access the Lake Tütira site. Blue McMillan is thanked for allowing access through his property to the mānuka planting, and for the use of his shed for processing sample plants excavated from this site. This paper was reviewed by Robyn Simcock and edited by Anne Austin. Additional figures were drafted by Nicolette Faville and Anne Sutherland of Manaaki Whenua Landcare Research. We thank the anonymous reviewers for their comments on the draft of this manuscript.

\section{Availability of data and materials}

Please contact the corresponding author for data requests.

\section{Funding}

This research was supported over several years from different sources including Manaaki Whenua - Landcare Research Strategic Science Investment Fund (SSIF), Plant and Food Research SSIF, Scion's “Growing Confidence in Forestry's Future" programme MBIE Contract No. C04X1306, and the Ministry for Primary Industries (MPI).

\section{References}

Aldridge, R., \& Jackson, R.J. (1968). Interception of rainfall by manuka (Leptospermum scoparium) at Taita New Zealand. New Zealand Journal of Science, 11(2), 301-317.

Aldridge, R., \& Jackson, R.J. (1973). Interception of rainfall by hard beech (Nothofagus truncata) at Taita, New Zealand. New Zealand Journal of Science, 16, 185-198.

Basher, L.R. (2013). Erosion processes and their control in New Zealand. In J.R. Dymond (Ed.), Ecosystem Services in New Zealand - Conditions and Trends (pp. 363-374). Lincoln, New Zealand: Manaaki Whenua Press.
Beets, P.N., \& Oliver, G.R. (2007). Water use by managed stands of Pinus radiata, indigenous podocarps/ hardwood forest, and improved pasture in the central North Island of New Zealand. New Zealand Journal of Forestry Science, 37(2), 306-323.

Bergin, D., Kimberley, M.O., \& Marden, M. (1995). Protective value of regenerating tea tree stands on erosion-prone hill country, East Coast, North Island, New Zealand. New Zealand Journal of Forestry Science, 25(1), 3-19.

Blake, G.J. (1965). Measurement of interception loss in tea tree. [Abstract]. Journal of Hydrology ( New Zealand), 4, 87.

Carson, M.A., \& Kirby, M.J. (1972). Hillslope Form and Process. Oxford, UK: Alden and Mowbray Ltd.

Clark, L.J., Price, A.H., Steel, K.A., \& Whalley, W.R. (2008). Evidence from near-isogenic lines that root penetration increases with root diameter and bending stiffness in rice. Functional Plant Biology, 35, 1163-1171. https://doi.org/10.1071/FP08132

Eden, D.N., Froggat, P.C., Trustrum, N.A., \& Page, M.J. (1993). A multiple source Holocene tephra sequence from Lake Tūtira, Hawke's Bay, New Zealand. New Zealand Journal of Geology and Geophysics, 36, 233-242. https://doi.org/10.1080/ 00288306.1993 .9514571

Ekanayake, J., Marden, M., Watson, A.J., \& Rowan, D. (1997). Tree roots and slope stability: A comparison between Pinus radiata (radiata pine) and Kunzea ericoides (kanuka). New Zealand Journal of Forestry Science, 27(2), 216-233.

Ekanayake, J.C., Phillips, C.J., \& Marden, M. (2004). A comparison of methods for stability analysis of vegetated slopes. In D.H. Barker, A.J. Watson, S. Sombatpanit, B. Northcutt, \& A.R. Maglinao (Eds.). Ground and Water Bioengineering for Erosion Control and Slope Stabilization. (pp. 171-181). Enfield, NH: Science Publishers.

Giadrossich, F., Schwarz, M., Cohen, D., Cislaghi, A., Vergani, C., Hubble, T., Phillips, C., \& Stokes, A. (2017). Methods to measure the mechanical behaviour of tree roots: A review. Ecological Engineering, 109, 256-271. https://doi. org/10.1016/j.ecoleng.2017.08.032

Glade, T.W. (1996). The temporal and spatial occurrence of landslide-triggering rainstorms in New Zealand. In R. Mäusbacher \& A. Schulte (Eds.), Beiträge zur Physiographie. Festschrift für Dietrich Barsch. Heidelberg Selbstverlag des Geographischen Instituts der Universität Heidelberg, 104, 237-250.

Hall, G.M.J. (2001). Mitigating an organisation's future net carbon emissions by native forest restoration. Ecological Applications, 11, 1622-1633. https:// doi.org/10.1890/1051-0761(2001)011[1622:MA OSFN]2.0.CO;2 
Hewitt, A.E. (2010). New Zealand Soil Classification. [Landcare Research Science Series No. 1]. Lincoln, New Zealand: Manaaki Whenua Press.

Hicks, D. (1991). Erosion under pasture, pine plantations, scrub and indigenous forest: A comparison from Cyclone Bola. New Zealand Forestry, 36(3), 21-22.

Hinds, H.V., \& Reid, J.S. (1957). Forest trees and timbers of New Zealand. [New Zealand Forest Service Bulletin 12]. New Zealand Forest Service, Rotorua, New Zealand.

Hurst, J.M., \& Allen, R.B. (2007). A permanent plot method for monitoring indigenous forests: field protocols. Lincoln, New Zealand, Landcare Research. 66 p

Jackson, R.J., \& Aldridge, R. (1973). Interception of rainfall by kamahi (Weinmannia racemosa) at Taita, New Zealand. New Zealand Journal of Science, 16, 573-590.

Kelliher, F.M., Whitehead, D., \& Pollock, D.S. (1992). Rainfall interception by trees and slash in a young Pinus radiata D.Don stand. Journal of Hydrology, 131, 187-204. https://doi.org/10.1016/00221694(92)90217-I

Ketterings, Q.M., Coe, R., van Noordwijk, M., Ambagau, Y., \& Palm, C.A. (2001). Reducing uncertainty in the use of allometric biomass equations for predicting above-ground tree biomass in the mixed secondary forests. Forest Ecology and Management, 146, 199-209. https://doi.org/10.1016/S03781127(00)00460-6

Lambie, S., Marden, M., Kirschbaum, M., Soliman, T., \& Walsh, P. (2018). Best options for land use following radiata harvest in the Gisborne District under climate change: Literature review. [MPI Technical Paper No. 2018/46]. Wellington, New Zealand: Ministry for Primary Industries. $74 \mathrm{p}$.

Lloreet, F., Casanovas, C., \& Peñuelas, J. (1999). Seedling survival of Mediterranean shrubland species in relation to root:shoot ratio, seed size and water and nitrogen use. Functional Ecology, 13, 210-216. https://doi.org/10.1046/j.13652435.1999.00309.x

Marden, M., \& Lambie, S. (2019). Plot-based, growth performance of space-planted mānuka (Leptospermum scoparium) on marginal land, and vulnerability to erosion. [Final report LC3488]. Christchurch, New Zealand: Manaaki Whenua Landcare Research.

Marden, M., \& Phillips, C. (2015). A review of research on the erosion control effectiveness of naturally reverting mānuka (Leptospermum scoparium) and kānuka (Kunzea ericoides var. ericoides): implications for erosion mitigation by space-planted mānuka on marginal land. [Envirolink Advice Grant C09X1424, 1562-HBRC210. Prepared for Hawke's Bay Regional Council. Landcare Research Contract Report LC 2280]. Christchurch, New Zealand:
Manaaki Whenua Landcare Research 47 p.

Marden, M., Phillips, C.J., \& Rowan, D. (1991). Declining soil loss with increasing age of plantation forests in Uawa catchment, East Coast region, North Island, New Zealand. In P. Henriques (Ed.), Proceedings, International Symposium on Sustainable Land Management, New Zealand. (pp. 358-361).

Marden, M., Rowan, D., \& Phillips, C. (1995). Impact of cyclone-induced landsliding on plantation forests and farmland in the East Coast region of New Zealand: A lesson in risk management? In (K. Sassa, Ed.) Proceedings of XX IUFRO World Congress, Technical session on Natural Disasters in Mountainous Areas, Finland, pp. 133-145.

Marden, M., Rowan, D., \& Phillips, C. (2005). Stabilising characteristics of New Zealand indigenous riparian colonising plants. Plant and Soil, 278, 95-105. https://doi.org/10.1007/s11104-004-7598-2

Marden, M., Lambie, S., \& Rowan, D. (2016). Root development and whole-tree allometry of juvenile trees of five seed lots of $P$. radiata D.Don: implications for forest establishment on erosionprone terrain, East Coast region, North Island, New Zealand. New Zealand Journal of Forestry Science, 46: 24. https://doi.org/10.1186/s40490-016$\underline{0082-\mathrm{y}}$

Marden, M., Lambie, S., \& Rowan, D. (2018a). Root system attributes of 12 juvenile indigenous early colonising shrub and tree species with potential for mitigating erosion in New Zealand. New Zealand Journal of Forestry Science, 48: 11. https:// doi.org/10.1186/s40490-018-0115-9

Marden, M., Lambie, S., \& Phillips, C. (2018b). Biomass and root attributes of 8 of New Zealand's most common indigenous evergreen conifer and broadleaved forest species during the first 5 years of establishment. New Zealand Journal of Forestry Science, 48: 9. https://doi.org/10.1186/s40490018-0113-y

Marden, M., \& Rowan D. (1993). Protective value of vegetation on Tertiary terrain during Cyclone Bola, East Coast, North Island, New Zealand. New Zealand Journal of Forestry Science, 23, 255-263.

Mazengarb, C., \& Speden, I.G. (2000). Geology of the Raukumara area. [Geological Map 6; 1:250,000]. Lower Hutt, New Zealand: Institute of Geological and Nuclear Sciences.

McPherson, A., \& Newstrom-Lloyd, L. (2018). Handbook for Mānuka Plantations and Farms: Profitable and Sustainable Mānuka Honey Harvesting. Wellington, New Zealand: Ministry for Primary Industries. 33 p.

Ministry for Primary Industries. (2015a). A guide to the Afforestation Grant Scheme. Wellington, New Zealand: Ministry for Primary Industries. http://www. mpi.govt.nz/funding-and-programmes/forestry/ afforestation-grant-scheme. Accessed 21 May 2017. 
Ministry for Primary Industries. (2015b). A guide to the Permanent Forest Sink Initiative. Wellington, New Zealand: Ministry for Primary Industries. http:// www.mpi.govt.nz/funding-and-programmes/ forestry/permanent-forest-sink-initiative/ afforestation. Accessed 02 August 2016.

Ministry for Primary Industries. (2016). A guide to the Erosion Control Funding Programme (East Coast). Wellington, New Zealand: Ministry for Primary Industries. http://www.mpi.govt.nz/funding-andprogrammes/forestry/erosion-control-fundingprogramme. Accessed 02 August 2016.

Ministry for Primary Industries. (2018). The One Billion Trees Programme: our future, our billion trees. Wellington, New Zealand: Ministry for Primary Industries. http://www.mpi.govt.nz/funding-andprogrammes/forestry/erosion-control-fundingprogramme. Accessed 04 September 2019.

National Water and Soil Conservation Organisation. (1976). New Zealand Land Resource Inventory worksheets. Wellington, New Zealand: New Zealand Government Printer.

Page, M.J. (1976). New Zealand Land Resource Inventory Northern Hawke's Bay Region: Land Use Capability extended legend. Wellington, New Zealand: National Water and Soil Conservation Organisation.

Page, M.J., Trustrum, N.A., \& De Rose, R.C. (1994). A high-resolution record of storm-induced erosion from lake sediments, New Zealand. Journal of Paleolimnology, 11, 333-348. https://doi. org/10.1007/BF00677993

Pearce, A.J., O'Loughlin, C.L., Jackson, R.J., \& Zhang, X.B. (1987). Reforestation: on-site effects on hydrology and erosion, eastern Raukumara Range, New Zealand. In H.R, Swanson, P.Y. Bernier \& P.D. Woodard (Eds.), Forest Hydrology and Watershed Management (pp. 489-497). [International Association of Hydrological Sciences Publication 167].

Phillips, C.J., Marden, M., Rowan, D., \& Ekanayake, J.C. (2001). Stabilising characteristics of native riparian vegetation in New Zealand. In Proceedings of 3rd Australian Stream Management Conference, Brisbane. August 2001 (pp. 507-512).

Phillips, C.J., Marden, M., \& Lambie, S. (2014). Observations of root growth of young poplar and willow planting types. New Zealand Journal of Forestry Science, 44: 15. https://doi.org/10.1186/ s40490-014-0015-6

Phillips, C.J., Marden, M., \& Lambie, S. (2015). Observations of "coarse" root development in young trees of nine exotic species from a New Zealand plot trial. New Zealand Journal of Forestry Science, 45: 13. https://doi.org/10.1186/s40490015-0043-X

Preston, N. (1999). Event-induced changes in land surface condition-implications for subsequent slope stability. Zeitschrift für Geomorphologie, 115, 157-173.

Rowe, L.K., Marden, M., \& Rowan, D. (1999). Interception and throughfall of kanuka (Kunzea ericoides var. ericoides), East Coast region, North Island, New Zealand, and implications for soil conservation. Journal of Hydrology (New Zealand), 38(1), 29-48.

Salter, R.T., Crippen, T.F., \& Noble, K.E. (1983). Storm damage assessment of the Thames-Te Aroha area following the storm of April 1981. [Publication 1]. Palmerston North, New Zealand: Soil Conservation Centre.

Schmidt, K.M., Roering, J.J., Stock, J.D., Dietrich, W.E., Montgomery, D.R., \& Schaub, T. (2001). Root cohesion variability and shallow landslide susceptibility in the Oregon Coast Range. Canadian Geotechnical Journal, 38, 995-1024. https://doi. org/10.1139/t01-031

Scholten, T., Goebes, P., Kühn, P., Seitz, S., Assmann, T., Bauhus, J., Bruelheide, H., Buscot, F., Erfmeier, A., \& Fischer, M . (2017). On the combined effect of soil fertility and topography on tree growth in subtropical forest ecosystems: a study from SE China. Journal of Plant Ecology, 10(1), 111-127. https://doi.org/10.1093/jpe/rtw065

Selby, M.J. (1967). Aspects of the geomorphology of the greywacke ranges bordering the lower and middle Waikato basins. Earth Science Journal, 1(1), 37-58.

Swanston, D.N., \& Swanson, F.J. (1976). Timber harvesting, mass erosion, and steepland forest geomorphology in the Pacific North West. In D.R. Coates (Ed.), Geomorphology and Engineering. (pp. 199-221). London: Routledge. https://doi. org/10.4324/9781003028826-10

Trotter, C., Tate, K., Scott, N., Townsend, J., Wilde, H., Lambie, S., Marden, M., \& Pinkney, T. (2005). Afforestation/reforestation of New Zealand marginal pasture lands by indigenous shrub lands: the potential for Kyoto forest sinks. Annals of Forestry Science, 62, 865-871. https://doi. org/10.1051/forest:2005077

Wagner, R.G., \& Ter-Mikaelian, M.T. (1999). Comparison of biomass component equations for four species of northern coniferous tree seedlings, Annals of Forestry Science, 56, 193-199. https://doi. org/10.1051/forest:19990301

Watson, A., \& Marden, M. (2004). Live root-wood tensile strengths of some common New Zealand indigenous and plantation tree species. New Zealand Journal of Forestry Science, 34(3), 344-353.

Watson, A., Marden, M., \& Rowan, D. (1995). Tree species performance and slope stability. In D.H. Barker (Ed.), Vegetation and Slopes: Stabilisation, Protection and Ecology. (pp. 161-171). Proceedings of Institute of Civil Engineers Conference. London: 
Thomas Telford Press. https://doi.org/10.1680/ vasspae.20313.0018

Watson, A.J., Marden, M., \& Rowan, D. (1997). Root-wood strength deterioration in kānuka after clearfelling. New Zealand Journal of Forestry Science, 27(2), 205-215.

Watson, A., \& O'Loughlin, C.L. (1985). Morphology, strength and biomass of mānuka roots and their influence on slope stability. New Zealand Journal of Forestry Science, 15(3), 337-348.

Watson, A.J., \& O'Loughlin, C.L. (1990). Structural root morphology and biomass of three age classes of Pinus radiata. New Zealand Journal of Forestry Science, 20, 97-110.

Watson, A.J., Phillips, C.J., \& Marden, M. (1999). Root strength, growth, and rates of decay: root reinforcement changes of two tree species and their contribution to slope stability. Plant and Soil, 217(1-2), 39-47. https://doi. org/10.1023/A:1004682509514

Watson, A.J., Phillips, C.J., \& Simcock, R. (1998). Rooting depth investigations of indigenous plants: Tailings dam embankment-Martha Gold Mine, Waihi. [Landcare Research Contract Report LC9798/90 prepared for Waihi Gold Mining Company Limited]. $31 \mathrm{p}$

Watson, A., \& Tombleson, J.D. (2002). Toppling in juvenile trees: A comparison of the root system characteristics of direct-sown seedlings, and bareroot seedlings and cuttings. Plant and Soil, 239, 187196. https://doi.org/10.1023/A:1015036105630

Watson, A., \& Tombleson, J.D. (2004). Toppling in young pines: Temporal changes in root system characteristics of bare-root seedlings and cuttings. New Zealand Journal of Forestry Science, 34(1), 2948.

Wu, T.H., McKinnell, W.P., \& Swanston, D.N. (1979). Strength of tree roots and landslides on Prince of Wales Island, Alaska. Canadian Geotechnical Journal, 16, 19-33. https://doi.org/10.1139/t79$\underline{003}$

Yost, M., Kitchen, N.R., Sudduth, K.A., \& Allphin Jnr, E. (2018). Miscanthus x giganteus growth and nutrient export on 22 Producer Fields. Bioenergy Research, 1192, 426-439. https://doi.org/10.1007/s12155018-9907-2 


\section{APPENDIX}

TABLE A1: Global Positioning System locations of PSPs established in mānuka planted in 2012, Lake Tutira, northern Hawke's Bay, New Zealand. Plot distribution in relation to landform units is shown on Figure 1.

\begin{tabular}{llll}
\hline Site number & Site code & Easting & Northing \\
\hline 3927 & Stable interfluve 1 & E2846931 & N6211704 \\
3931 & Stable interfluve 2 & E2847097 & N6211758 \\
3933 & Stable interfluve 3 & E2847542 & N6212106 \\
3928 & Landslide scar 1 & E2847022 & N6211611 \\
3929 & Landslide scar 2 & E2846997 & N6211662 \\
3932 & Landslide scar 3 & E2847434 & N6211811 \\
3930 & Colluvial slope 1 & E2847008 & N6211740 \\
3934 & Colluvial slope 2 & E2847262 & N6212128 \\
3935 & Colluvial slope 3 & E2847206 & N6212018 \\
\hline
\end{tabular}

TABLE A2: Regression analyses based on canopy radius and area, and root radius and area of 3-, 4-and 6-year-old mānuka planted at Lake Tutira, northern Hawke's Bay, New Zealand. Canopy data are based on incremental changes in crown width (diameter) of trees within PSPs. Changes in root system diameter are based on trees excavated from the study site.

\begin{tabular}{lllllllll}
\hline Regression & \multicolumn{2}{l}{ Canopy radius (m) } & \multicolumn{2}{c}{ Canopy area (m) } & \multicolumn{2}{c}{ Root radius (m) } & \multicolumn{2}{c}{ Root area $\left(\mathbf{m}^{2}\right)$} \\
& $\mathbf{r}^{2}$ & $\boldsymbol{P}$ & $\mathbf{r}^{\mathbf{2}}$ & $\boldsymbol{P}$ & $\mathbf{r}^{\mathbf{2}}$ & $\boldsymbol{P}$ & $\mathbf{r}^{\mathbf{2}}$ & $\boldsymbol{P}$ \\
\hline Linear & 0.52 & $<0.001$ & 0.51 & $<0.001$ & 0.71 & $\mathbf{0 . 0 0 9}$ & 0.65 & $\mathbf{0 . 0 1 6}$ \\
Quadratic & 0.53 & $<0.001$ & 0.51 & $<0.001$ & 0.72 & 0.041 & 0.65 & 0.073 \\
Cubic & 0.53 & $<0.001$ & 0.51 & $<0.001$ & 0.72 & 0.132 & 0.65 & 0.202 \\
Power & 0.52 & $<0.001$ & 0.51 & $<0.001$ & 0.02 & 0.914 & 0.001 & 0.935 \\
Logarithmic & 0.53 & $<0.001$ & 0.51 & $<0.001$ & 0.71 & $\mathbf{0 . 0 0 9}$ & 0.65 & $\mathbf{0 . 0 1 6}$ \\
\hline
\end{tabular}

